\title{
Wolność wypowiedzi a zjawisko manipulacji przekazem prasowym
}

$\dot{z}$ aden akt prawny, zarówno prawa międzynarodowego publicznego, jak i akty mieszczące się w systemie polskiego prawa konstytucyjnego, nie definiują ani pojęcia „wolność człowieka”, ani ,prawa człowieka”. Pozwala to na formułowanie stanowisk, że prawnicza koncepcja wolności i praw człowieka jest wtórna wobec założeń filozoficznych ${ }^{1}$. Jest rzeczą jasną i oczywistą, iż wolności i prawa człowieka - jak rzadko które konstrukcje prawne - pozostają w ścisłym związku z koncepcjami filozoficznymi i systemem aksjologii, które te koncepcje niosą. Szczególnie istotny wydaje się wkład koncepcji liberalnych oraz myślicieli jak Rudolf Sammler, Gustaw Radbruch, Lon Louis Fuller, którzy starali się znaleźć rozwiązanie sporu między szkołą prawnonaturalną i pozytywistyczna, postulując odwołanie się do pojęcia sprawiedliwości prawa, czyli: sprawiedliwości w postępowaniu $i$ dochodzeniu do prawa. Niektórzy dopatrują się źródeł koncepcji wolności i praw człowieka w myśli prawnonaturalnej, inni widzą ich początki w postulatach myślicieli socjalistycznych, jeszcze inni zdają się wiązać je z myślą społeczną Kościoła katolickiego ${ }^{2}$. Pozostawiając tą interesującą problematykę historykom doktryn historycznych i prawnych oraz tym badaczom, którzy poświęcają uwage dziejom myśli politycznej, wypada odnotować, iż współcześnie istnieją różne definicje tych terminów. Najczęściej uważa się, że są to zarówno wolności jednostki, jak i jej uprawnienia, będące podstawą żądania od państwa lub innych podmiotów określonych działań. Czasami podkreśla się, że część z nich ma charakter naturalny i niezmienialny, inne zaś są wyłącznie wyrazem woli państwa ${ }^{3}$. Tak więc, skonstatować należy istnienie pewnych rozbieżności definicyjnych ${ }^{4}$. Warto zauważyć, iż w nauce

${ }^{1}$ M. Piechowiak, Pojęcie praw człowieka, w: Podstawowe prawa jednostki i systemy ich ochrony, red. L. Wiśniewski, Warszawa 1997, s. 8.

${ }^{2}$ B. Banaszak, Ogólne wiadomości o prawach człowieka, w: Prawa i wolności obywatelskie w konstytucji RP, red. B. Banaszak, A. Preisner, Warszawa 2002, s. 1-63; także: E. Styliandis, Wplyw antycznej cywilizacji greckiej na rozwój praw człowieka, w: Prawa człowieka. Geneza, koncepcje, ochrona, red. B. Banaszak, Wrocław 1993, s. 121; tamże, M. Nowak, Trzy generacje praw człowieka, s. 114; ks. J. Mazurek, Godność osoby ludzkiej podstawa prawa człowieka, Lublin 2001, s. 17 i n.; Z. Kędzia, Współczesna burżuazyjna koncepcja praw, wolności i obowiazków obywatelskich, w: Prawa i obowiqzki obywatelskie w Polsce i świecie, Warszawa 1974, passim; tenże, Burżuazyjna koncepcja praw człowieka, Wrocław-Warszawa-Kraków-Gdańsk 1980, s. 24-84; K. Opałek, Koncepcja praw, wolności i obowiqzków człowieka i obywatela. Jej geneza i charakter, w: Prawa i obowiqzki obywatelskie..., s. 13-22, ks. S. Kowalczyk, Filozofia wolności, Lublin 1999, s. 240; tenże, Wolność naturq i prawem człowieka. Indywidualny i społeczny wymiar wolności, Sandomierz 2000; W. Zakrzewski, Podstawowe wolności, prawa i obowiqzki człowieka i obywatela, w: Polskie prawo konstytucyjne, red. W. Skrzydło, Lublin 2005, wyd. III, s. 149-173; M. Chmaj, Pojęcie i geneza wolności i praw człowieka, w: Konstytucyjne wolności i prawa w Polsce, Zakamycze 2002, s. 14-19.

${ }^{3}$ Omówienie definicji praw człowieka przynosi m.in. praca B. Banaszaka, Prawa jednostki i systemy ich ochrony, Wrocław 1995, s. 5-21; zob. także: C. Mik, Koncepcja normatywna europejskiego prawa praw człowieka, Toruń 1994.

${ }^{4}$ Zob. R. Kuźniar, Prawa człowieka. Prawo, instytucje, stosunki międzynarodowe, Warszawa 2000, s. 12; W. Osiatyński, Wprowadzenie do pojęcia praw człowieka, w: Szkoła Prawa Człowieka. Teksty wykładów, Warszawa 
trwają dość istotne spory o pojęcie i typologię praw człowieka oraz o zakres praw i wolności obywatelskich, praw i wolności konstytucyjnych, podstawowych praw i wolności, praw podmiotowych, publicznych praw podmiotowych, a także - w kwestii klasyfikacji praw jednostki ${ }^{5}$.

Nie wszyscy chcą także zauważyć genezę praw człowieka i dostrzec ich rozwój. Nie widzą podstaw i powodów, aby zastanawiać się nad pochodzeniem tych praw ${ }^{6}$. Pomija się problem, czy między państwem prawa a prawami człowieka istnieje swoiste iunctim, czy też pozostają one w całkowitej lub częściowej antynomii ${ }^{7}$. Nie sposób w rym miejscu dokonać przeglądu dyskusji nad koncepcjami państwa prawa, zarówno w literaturze światowej, jak i w polskiej, czy podejmować trud dokonania uściśleń terminologicznych, bądź klasyfikacyjnych $^{8}$. Wypada zauważyć, że kwestie te doczekały się już mniej lub bardziej pogłębionych studiów w literaturze naukowej ${ }^{9}$. Z natury rzeczy wypadało pominąć także kwestie dotyczące genezy, siatki pojęciowej oraz zakresu i charakteru praw człowieka - odsyłając także w tym

1996, s. 14; I. Malinowska, Prawa człowieka w Unii Europejskiej, Warszawa 2005, s. 9-17; L. Wiśniewski, Prawo a wolność człowieka - pojęcie i konstrukcja prawna, w: Podstawowe prawa jednostki i ich sqdowa ochrona, red. L. Wiśniewski, Warszawa 1997, s. 55-57; M. Wyszkowski, Granice praw $i$ wolności-granice władzy, w: Obywatel - jego wolności i prawa, Warszawa 1998, s. 59; K. Wojtyczek, Granice ingerencji ustawodawczej w sfere praw czlowieka w Konstytucji RP, Zakamycze 1999, s. 15-24.

${ }^{5}$ Kwestie te w sposób szczegółowy i kompetentny omówił B. Banaszak, w tegoż, Prawa jednostki i systemy..., Wrocław 1995, s. 6-21. Zob. także: A. Michalska, Prawa człowieka w systemie norm międzynarodowych, Warszawa-Poznań 1982, s. 113.

${ }^{6}$ Problematykę tę poruszył w fascynującym eseju Jan Baszkiewicz, zob. J. Baszkiewicz, Filozoficzne i praktyczne dylematy praw czlowieka, w: Meandry tradycji i zakręty ponowoczesności, opr. D. Kurczewski, Rzeszów 2002, s. $49-62$.

${ }^{7}$ Niektóre z tych kwestii podjął Henryk Olszewski, zob.: H. Olszewski, Odchodzeniu od demokracji (Kilka uwag historyka prawa), „Państwo i Prawo” 2006, z. 8 (726), s. 3-15 (referat wygłoszony na posiedzeniu Komitetu Nauk Prawnych Polskiej Akademii Nauk w dniu 1 IV 2006, zob. sprawozdanie, ten sam zeszyt, s. 107 i n.).

${ }^{8}$ W przedmiocie genezy państwa prawnego zob.: I. v. Münch, Staatsrecht, t. 1, Stuttgart-Berlin-Köln 1993, s. 135; H. Schanbeck, Von Sinnwandel des Rechtstaates, Schriftenreine der Juristischen Gesselschaft e. V. Berlin, Berlin 1970, s. 1-17.

${ }^{9}$ W kwestii pojęcia „państwo prawa” zob.: M. Zmierczak, Kształtowanie się koncepcji państwa prawnego na przykładzie niemieckiej myśli prawnej, w: Polskie dyskusje o państwie prawa, red. S. Wronkowska, Warszawa 1995, s. 11-27. Znaczna część przywołanego tekstu została opublikowana wcześniej pod tym samym tytułem w: Demokratyczne państwo prawne (aksjologia, struktura, funkcje). Studia i szkice, red. H. Rot, Wrocław 1994, s. 53-68; S. Wronkowska, Zarys koncepcji państwa prawnego w polskiej literaturze politycznej i prawnej, w: Polskie dyskusje o państwie prawa, red. S. Wronkowska, Warszawa 1995, s. 63-80; także, Klauzula państwa prawnego, w: Podstawowe problemy stosowania Konstytucji Rzeczypospolitej Polskiej. Raport wstepny, red. K. Działocha, Warszawa 2004, s. 11-28; W. Sokolewicz, Państwo prawne-jego cechy i kryteria, Wydawnictwo Kancelarii Sejmu. Informacja nr 63 Biura Studiów i Ekspertyz, Warszawa 1992, s. 3 i n.; K. Działocha, Państwo prawne w warunkach zasadniczych zmian systemu prawa RP, „Państwo i Prawo” 1992, z. 1, s. 17; M. Wyrzykowski, Legislacja-demokratyczne państwo prawne - radykalne reformy polityczne i gospodarcze, $\mathrm{w}$ : Tworzenie prawa $w$ demokratycznym państwie prawnym, red. H. Suchocka, Warszawa 1997, s. 40 i n.; tenże, Zasada demokratycznego państwa prawnego, w: Zasady podstawowe w polskiej Konstytucji, red. W. Sokolewicz, Warszawa 1998, s. 65-91, szczególnie 66-70; M. Pietrzak, Model demokratycznego państwa prawnego, „Studia Konstytucyjne” t. VII, s. 14 i n.; tenże, Demokratyczne państwo prawne, „Przegląd Humanistyczny” 1999, nr 6; przedr. tegoż, Demokratyczne świeckie państwo prawne, Warszawa 1999, s. 27-42; P. Tuleja, Zastane pojęcie państwa prawnego, w: Zasada demokratycznego państwa prawnego w Konstytucji RP, red. S. Wronkowska, Warszawa 2006, s. 49-72; J. Zakrzewska, Konstytucyjna zasada państwa prawnego w praktyce Trybunału Konstytucyjnego, „Państwo i Prawo” 1992, z. 7, s. 10; K. Jonca, Ewolucja pojęcia „państwo prawne” w niemieckiej doktrynie prasowej, „Acta Universitatis Wratislawiensis” nr 307, „Przegląd Prawa i Administracji”, t. 7, Wrocław 1976; J. Stelmach, Filozoficzne aspekty dyskusji o państwie prawnym, w: Prawo w zmieniajacym się społeczeństwie, red. G. Skąpska, Kraków 1992, s. 221-228. W tekście zanalizowano trzy koncepcje państwa prawnego, a mianowicie: państwa ustaw - Gesetzesstaat, państwa sędziów - Richterstaat, państwa prawnego - Rechtsstaat. 
względzie do ustaleń doktryny. Czyniąc to nie wolno jednak zapominać o tym, że zarówno pojęcie „państwa prawa”, bywając niejednoznacznie rozumiane, różnie interpretowane, tak samo przez doktrynę, jak i literaturę ${ }^{12}$.

U źródeł państwa prawnego leży chęć ograniczenia samowoli państwa o zagwarantowanie jednostce przynajmniej minimum praw, chociażby w postaci równości wobec norm stanowionych i stosowanych przez państwo. Zgodzić się jednak należy z tezą, że pewność granic między władzą a wolnością pozostawia jeszcze nierozstrzygnięte zagadnienie faktycznego rozmiaru wolności. Dylemat ten wydaje się tym trudniejszy do rozwiązania, że wbrew powszechnym przekonaniom nie istnieje i nie może istnieć absolutna wolność, a granice każdej wolności wyznacza przepis prawny. W doktrynie istnieje silna, aczkolwiek wcale nie powszechna tendencja odróżniania „,wolności” od ,praw”. Niektórzy badacze traktują jednak wolności jako specyficzny rodzaj praw obywatelskich, częstokroć dzieląc prawa jednostki na „uprawnienia” (prawa sensu sricto) i wolności. Generalnie przyjmuje się, że prawa i wolności przysługują określonemu podmiotowi. Jak stwierdza Leszek Wiśniewski, znamieniem „wolności” jest to, że nie wynika ona, zarówno jako wolność człowieka, jak i wolność obywatela, z prawa $\mathrm{w}$ znaczeniu przedmiotowym, a prawo jedynie ustanawia granice wolności. Poprzez

${ }^{10}$ M. Kordela, Państwo praworzqdne i państwo prawne-stosunek pojęć, w: Filozofia prawa i a tworzenie i stosowanie prawa. Materiaty ogólnopolskiej konferencji naukowej organizowanej w dniach 11 i 12 czerwca 1991 w Katowicach, red. B. Czech, Katowice 1992, s. 413; także, Zarys typologii uzasadnień aksjologicznych w orzecznictwie Trybunału Konstytucyjnego, Bydgoszcz-Poznań 2001, passim; J. Wróblewski, Z zagadnień pojęcia ideologii demokratycznego państwa prawnego (analiza teoretyczna), „Państwo i Prawo”, z. 6, s. 9; M. Sobolewski, Koncepcja państwa prawnego (Rechstaat) w doktrynie niemieckiego liberalizmu epoki klasycznej (do 1866), „Państwo i Prawo” 1980, z. 2, s. 130 i n.; R. Radwański, Socjalne państwo prawne w doktrynie RFN 1949-1969, Opole 1985, passim; L. Morawski, Spór o pojęcie państwa prawnego, „Państwo i Prawo” 1994, z. 4, s. 17.

${ }^{11}$ Literatura dotycząca praw człowieka jest wyjątkowo obszerna. Wskazać należy jednak na niektóre z opracowań, ograniczając się do tekstów w języku polskim. Wśród nich zobacz: R: Wieruszewski, Prawa człowieka. Model prawny, Wrocław-Warszawa-Kraków 1991, passim; W. Osiatyński, Filozofia i historia praw człowieka, w: Prawa człowieka a policja. Problemy teorii i praktyki, Legionowo 1994, s. 34 i n.; tenże, Demokracja a prawa czlowieka, w: Prawa człowieka w społeczeństwie obywatelskim, red. A. Rzepliński, Warszawa 1993, s. 39; K. Sójka-Zielińska, Drogi i bezdroża prawa, Wrocław-Warszawa-Kraków 2000, s. 88 i n.; B. Banaszak, Ogólne widomości o prawach człowieka, w: Prawa i wolności obywatelskie w Konstytucji RP, red. B. Banaszak, A. Preisner, Warszawa 2002, s. 17-28; tenże, Prawa jednostki i systemy ich ochrony, Wrocław 1995, s. 48 i n.; A. Michalska, Prawa człowieka w systemach norm międzynarodowych, Warszawa-Poznań 1982, s. 18; taże, Podstawowe prawa człowieka w prawie wewnętrznym a pakty praw człowieka, Warszawa 1976, s. 105; C. Mik, Koncepcja normatywna europejskiego prawa praw człowieka, Toruń 1994, s. 17 i n.; R. Kuźniar, Prawa człowieka. Prawo, Instytucje, stosunki międzynarodowe, Warszawa 2006, szczególnie s. 19-100; Ochrona prawa człowieka w świecie, red. L. Wiśniewski, Bydgoszcz-Warszawa 2000, passim; tenże, Konstytucyjne podstawy ochrony wolności i praw człowieka w Polsce, ,Studia Prawnicze" 2003, z. 3 (157), s. 35-62; tenże, Wolności i prawa jednostki oraz ich gwarancje w praktyce, w: Podstawowe problemy stosowania Konstytucji Rzeczypospolitej Polskiej. Raport wstęnny, red. K. Działocha, Warszawa 2004, s. 93-152; B. Banaszak, A. Bisztyga, K. Complak, M. Jabłoński, R. Wieruszewski, K. Wójtowicz, System ochrony praw człowieka, Zakamycze 2003, szczególnie s. 13-32; P. Daranowski, Międzynarodowa ochrona praw obywatelskich i politycznych in statu nascendi Międzynarodowy Pakt Praw Obywatelskich i Politycznych, Łódź 1993, s. 14; M. Jabłoński, S. Jarosz-Żukowska, Prawa człowieka i systemy ich ochron. Zarys wykładu, Wrocław 2004, szczególnie s. 16-60, tamże, dość obszerna bibliografia, s. 314-347; M. Nowak, Trzy generacje praw człowieka, ich znaczenie w świetle przesłanek ideowych oraz w świetle ich genezy, w: Prawa człowieka, geneza, koncepcja, ochrona, Wrocław 1993, s. 116-117; P. Tuleja, Normatywna treść praw jednostki w ustawach Konstytucji RP, Warszawa 1997, passim, szczególnie s. 9-28; A. Przyborowska-Klimczak, Europejski system ochrony praw człowieka, ,Roczniki Nauk Prawnych” 1991-1992, s. 132; J. Symonides, Polska w europejskich systemach praw człowieka, ,Roczniki Polskiej Polityki Zagranicznej”, Warszawa 2002, s. 193.

${ }^{12}$ E. Morawska, Klauzula państwa prawnego w Konstytucji RP na tle orzecznictwa Trybunału Konstytucyjnego, Toruń 2003, s. 153-378. 
normy prawne państwo ma także obowiązek chronić wolności w zakresie, w którym nie zostały one innymi normami prawnymi ograniczone. Konstatacja ta legła u podstaw konstrukcji „praw negatywnych”, czyli takich, które są zakazami ingerowania przez państwo w określone obszary życia jednostki. Uznając finezję prawniczą tego sformułowania, wypada jednak zauważyć, iż ruchy społeczne i poszczególne osoby nie walczyły, jak dotąd nigdy, o ,,prawa negatywne”, natomiast domagały się poszanowania wolności człowieka i wolności obywatela, ewentualnie przyznania bądź respektowania określonych praw. Niekiedy, widząc różnicę między „prawami” a „wolnościami”, dzieli się te ostatnie na wolności osobiste i polityczne. Te pierwsze mają, według tej koncepcji, przysługiwać wszystkim osobom bez względu na ich obywatelstwo, tymi drugimi - politycznymi - kontentować się mają tylko obywatele konkretnego państwa ${ }^{13}$. Problem w tym, czy wyznaczając granice praw i wolności, prawodawca może czynić to zupełnie dowolnie, kierując się sobie tylko znanymi przesłankami, czy też taką bezwzględną dowolnością nie dysponuje, a przynajmniej nie dysponuje nią wówczas, gdy chce uchodzić za twórcę prawa w państwie prawnym. W obecnie obowiązującej Konstytucji Rzeczypospolitej Polskiej granicę taką stanowi art. 31 ust. 3. Unormowanie to ma charakter lex generalis, a więc odnosi się do wszystkich wolności i praw, niezależnie od tego, czy przepisy szczegółowe odrębnie określają przesłanki ograniczenia danego prawa czy wolności ${ }^{14}$.

Dylemat wokół kwestii tego w jakim zakresie państwo (i to państwo prawne) ma możność wkraczania w sferę praw człowieka zwraca uwagę na warstwę aksjologiczną, nasuwa pytanie czy państwo mające charakter demokratyczny i będące państwem prawa - a więc osiagające współczesny ideał dobrego państwa, może (a jeśli tak to w jakim zakresie) dokonywać regulacji w płaszczyźnie praw i wolności człowieka ${ }^{15}$. Państwo demokratyczne przez lata było w Polsce wytęsknionym, nieosiągalnym ideałem - marzeniem, którego spełnienie miało raz na zawsze rozwiązać nabrzmiałe problemy polityczne ${ }^{16}$. Mówiąc o państwie demokratycznym czy o demokratycznym państwie prawnym, mniej lub bardziej świadomie chciano rozumieć pod tym określeniem socjalne państwo prawa, rozmyślnie lub przypadkowo nawiązując do rozwiązań niemieckich. Nikt oczywiście przy tej okazji nie chciał pamiętać, że w doktrynie niemieckiej spory co do normatywnego charakteru socjalnego państwa prawa

\footnotetext{
${ }^{13}$ Por. w tym przedmiocie: L. Wiśniewski, Prawo a wolność człowieka-pojęcie i konstrukcja prawna, w: Podstawowe prawa jednostki i ich sqdowa ochrona, red. L. Wiśniewski, Warszawa 1997, s. 51 i n.; Prawa człowieka, geneza, koncepcje, ochrona, red. B. Banaszak, Wrocław 1993; L. Wiśniewski, Zakres ochrony prawnej wolności człowieka $i$ warunki ich dopuszczalnych ograniczeń $w$ praktyce, w: Wolności i prawa jednostki i ich gwarancje w praktyce, red. L. Wiśniewski, Warszawa 2006, s. 21-34; B. Banaszak, Ogólne wiadomości o prawach człowieka, w: Prawa i wolności obywatelskie w Konstytucji RP, Warszawa 2000, s. 1-63; także S. Gebethner, Ustrój polityczny Polskiej Rzeczypospolitej Ludowej, Warszawa 1976, s. 152-152.

${ }^{14}$ M. Wyrzykowski, Granice praw i wolności - granice władzy, w: Obywatel - jego wolności i prawa, opr. B. Oliwa-Radzikowska, Warszawa 1998, s. 55. Podobnie widzą ten problem: K. Wojtyczek, Granice ingerencji ustawodawczej w sferę praw człowieka w Konstytucji RP, Kraków 1999, s. 81-83; A. Łabno, Ograniczenie wolności praw człowieka na podstawie artykułu 31 Konstytucji RP, w: Prawa i wolności obywatelskie w Konstytucji RP, pod red. B. Banaszaka, A. Preisnera, Warszawa 2002, s. 694; a także, D. Dudek, Konstytucyjna wolność człowieka a tymczasowe aresztowanie, Lublin 1999, s. 112 i n. Odmiennie zdaje się interpretować tę kwestię P. Winczorek, Komentarz do Konstytucji Rzeczypospolitej Polskiej z dnia 2 kwietnia 1997 roku, Warszawa 2000, s. 49.

15 J. Mikołajewicz, M. Smolak, Zasada demokratycznego państwa prawnego w aksjologii Konstytucji Rzeczypospolitej Polskiej, w: Zasada demokratycznego państwa..., s. 90-100.

${ }^{16}$ E. Łętowska, Trudności w przyswajaniu w Polsce praktyki państwa prawa, w: Zasada demokratycznego państwa..., s. 195 i n.; tejże, Bariery naszego myślenia o prawie w perspektywie integracji z Europa, „Państwo i Prawo” 1996, z. 4-5, s. 12.
} 
trwają praktycznie po dzień dzisiejszy i chyba nigdy nie zostaną rozwiązane ${ }^{17}$, aczkolwiek trzeba przyznać, że niemiecki Federalny Trybunał Konstytucyjny nie widzi kolizyjności pojęć „,socjalny” i ,prawny” w określeniu „,socjalne państwo prawne” ${ }^{18}$. Państwo demokratyczne to nie tylko państwo, w którym sprawnie działają wszystkie jego organy, a prawo jest przestrzegane zarówno przez nie, jak i przez obywateli. Jest to niewątpliwie państwo praworządne, którego cechą jest zasada podziału władzy, rozumiana tak, jak pojmował to Charles Louis de Secondat, baron de la Brède et de Montesquieu ${ }^{19}$. Jest to także państwo, w którym stosunki między obywatelami a organami władzy są regulowane przez konstytucję, której prymat nad innymi aktami prawa nie podlega dyskusji ${ }^{20}$. Podkreśla się zwykle, że u podstaw demokratycznego państwa prawnego leży zasada zaufania obywateli do prawa, które powinno ucieleśniać określony system wartości akceptowanych przez społeczeństwo, wiążąc $w$ ten sposób władzę państwową. Państwo takowe ma służyć dalekosiężnym celom społecznym, mającym wszakże oparcie i uzasadnienie w wartościach społecznie akceptowanych. Obywatele, będąc równi wobec prawa winni w takim państwie cieszyć się gwarancjami szerokiej ochrony prawnej, sprawowanej przez niezawisłe sądy, w ramach ściśle określonych przepisami prawa procesowego. Istnieć też musi system odpowiedzialności funkcjonariuszy państwowych. W doktrynie, zwłaszcza niemieckiej, zauważa się, że do zasad państwa prawnego zalicza się proporcjonalność w zakresie środków i celów, przewidywalność i obliczalność państwowej ingerencji. Żadna z władz w demokratycznym państwie prawnym, ani żadna z instytucji w nim istniejących nie może traktować państwa jako narzędzia do osiągania celów, ale jako miarę własnego postępowania. Innymi słowy, demokratyczne państwo prawne to państwo, w którym istnieje autonomiczny względem niego system prawa, oparty na konstytucji, stanowiony $\mathrm{w}$ demokratycznym procesie, zaopatrzony $\mathrm{w}$ gwarancję przestrzegania i stosowania prawa, którego normy charakteryzują się tożsamością lub daleko idącą zbieżnością z syste-

${ }^{17}$ Por. E. Menzel, Die Socialstaatlichkeit als Verfassungsprinzip der Bundesrepublik, w: Der bünderliche Rechtsstaat, Frankfurt am Main 1978, Band 2; P. Kunig, Rechtstaatprinzip. Überlegungen zu seiner Bedeutung für das Verfassungrecht der Bundesrepublik Deutschland, München 1977. Analizę sporów w literaturze niemieckiej przedstawiają: J. Burska-Cieślak, Geneza pojęcia socjalnego państwa prawnego, w: Państwo, Ustrój, Konstytucja, Lublin 1991, s. 27 i n.; W. Góralski, Koncepcja państwa społecznego w teorii i praktyce konstytucyjnej RFN, „Przegląd Zachodni” 1976, nr 2; R. Radwański, Konstytucyjna ochrona „, demokratycznego, socjalnego i prawnego” ustroju RFN przed zagrożeniem wewnętrznym, „Przegląd Stosunków Międzynarodowych” 1973, nr 3; M. Smolak, Między koncepcja państwa socjalnego a koncepcja Rechtsstaat, w: Polskie dyskusje o państwie prawa, red. S. Wronkowska, Warszawa 1995.

18 J. Müller-Volbehr, Der soziele Rechtsstaatim System des Grundgesetzes, „JuristenZeitung” 1984, z. 2

${ }^{19}$ Godzi się przypomnieć, że wbrew temu co sądzą niektórzy publicyści i dziennikarze, podział władzy według Monteskiusza nie sprowadzał się do wydzielenia władzy ustawodawczej, wykonawczej i sądowniczej, lecz do opracowania całego systemu hamulców, zarówno wewnątrz każdej z nich, jak i separujących je wzajemnie od siebie i wykluczających możliwość ingerencji w działanie pozostałych. System ten ma zrównoważyć pozycję władz i rozgraniczyć ich kompetencje, a przede wszystkim wyeliminować zjawisko dominacji którejkolwiek, starając się zapewnić układ jak najbardziej zrównoważony. Zob. Monteskiusz i jego dzieło. Sesja naukowa w dwusetna rocznicę śmierci, Wrocław 1956, passim; M. Richter, The Political Philosophy of Montesquieu, New York 1977, passim; L. Althuser, Montesquieu. La politique et l'histoire, Paris 1985, passim; Th. L. Pangle, Montesquieu's Philosophy of Liberalism. A Commentary on the Spirit of Laws, Chicago 1989, passim.

${ }^{20}$ L. Garlicki, Materialna interpretacja klauzuli demokratycznego państwa prawnego w orzecznictwie Trybunału Konstytucyjnego, w: Zasada demokratycznego państwa..., s. 123-139. Akcentuje to silnie Sławomira Wronkowska, zauważając, że we współczesnym demokratycznym państwie władza ustawodawcza ma ograniczoną swobodę kształtowania treści norm prawnych, gdyż jest zobowiązana respektować prawa człowieka, zarówno te wysłowione w konstytucji, jak i wynikające ze zobowiązań międzynarodowych. Zob. S. Zmierczak, Jednostka a władza prawodawcza. Przyczynek do dyskusji, w: O prawach człowieka. W podwójna rocznicę Paktu. Księga pamiatkowa w hołdzie Prof. Annie Michalskiej, red. T. Jasudowicz, C. Mik, Toruń 1996, s. 75. 
mem wartości powszechnie akceptowanym. W państwie tym zasięg celów, których realizacja jest dopuszczalna przez zasięg prawa, ograniczona jest przez reguły i zasady praworządności regulujące zakres instrumentalności państwa ${ }^{21}$. Normy określające podstawy funkcjonowania instytucji publicznych nie mogą być więc odczytywane, rozumiane, wykładane i stosowane bez odniesienia do aksjologii państwa demokratycznego. Naruszenie wspomnianego systemu wartości tym samym powinno być postrzegane jako naruszenie zasad państwa prawa. Rodzi to z natury rzeczy pytanie, czy wspomniany system aksjologiczny może być ukształtowany dowolnie, czy też jest on stały i niezmienny dla każdego realnie istniejącego państwa, chcącego uchodzić za demokratyczne państwo prawa ${ }^{22}$. Konsekwencją takiego postawienia sprawy jest problem czy system aksjologiczny, leżący u podstaw państwa prawnego, może zostać narzucony przez jakąś grupę społeczną (stowarzyszenie, związek, partię, kościół itp.). Odpowiedź na te wątpliwości nie jest prosta. O ile nie budzi sprzeciwu teza, że w demokratycznym państwie prawa władze publiczne mogą działać tylko na podstawie przepisów prawa i czynić wyłącznie to, na co one mu pozwalają (lub to, co mu nakazuja), a obywatele podejmować wszelkie działania, które nie są zakazane przez prawo - o tyle w praktyce spornym być może istnienie jedynego systemu wartości właściwego demokratycznemu państwu prawa. Zakładając, iż nie jest możliwe narzucenie systemu aksjologicznego przez węższą lub szerszą grupę społeczną, a także, że nie ma jedynego wspólnego wszystkim demokratycznym państwom prawa systemu wartości ${ }^{23}$, można by zasadnie - aczkolwiek w sposób niezwykle przewrotny - przyjąć, iż system aksjologiczny państw autorytarnych, w tym także totalitar-

${ }^{21}$ R. Herzog, Kommentar zur Art. 20 des GG, (Lft. 18, September 1980), w: R. Maunz, G. Düring, R. Herzog, R. Scholtz, Grundgesetz. Kommentar, München 1993, s. 264-265; E. Schmidt-Assmann, Der Rechtsstaag, w: Handbuch des Staatsrechts der Bundesrepublik Deutschland, red. J. Isensee, P. Kirchof, Heidelberg 1987, s. 997.

${ }^{22}$ Warto zauważyć, że w projekcie Konstytucji z 20 stycznia 1995 roku przyjętym przez Komisję Redakcyjną Zagadnień Ogólnych i Przypisów Wprowadzających, w przypisie dotyczącym ograniczeń praw człowieka użyty został termin „,społeczeństwo demokratyczne”. Materiały z prac nad projektem Komisji nie wyjaśniają motywów, jakimi kierowali się członkowie Komisji Konstytucyjnej, wprowadzając w miejsce tego określenia ,państwo demokratyczne”. Wolno jednak przypuszczać, iż powodem była chęć zachowania jednolitości terminologicznej. Niemniej, w literaturze - w szczególności dotyczącej praw człowieka - oba terminy są stosowane, a Europejska Konwencja Praw Człowieka i Podstawowych Wolności oraz Pakty Praw Człowieka posiłkują się wprost sformułowaniem,,społeczeństwo demokratyczne". Jednak ani Europejska Komisja Praw Człowieka, ani żaden z organów Rady Europy nie podejmują próby określenia zasad, na których opiera się społeczeństwo demokratyczne. Zob. w tym przedmiocie: K. Wojtyczek, Granice ingerencji ustawodawczej w sferę praw czlowieka, Zakamycze 1999, s. 169-170. W kwestii pojęcia ,demokratyczne społeczeństwo” w międzynarodowym systemie praw człowieka: W. Berka, Die Gesetzesvrbehalte der Europäischen Menschenrechtskonvention, Österreichische Zeitschrift für Öffentliches Recht und Völkerrecht, 1986, s. 71 i n., w szczególności s. 91-98; O. Garibaldi, On the Ideoligical Content of Human Rights Instruments: The Clouse ,, in a Democratic Society”, w: Contemporary Issues in International Law. Essays in Honor of Louis B. Sohn, red. Buengertal, Kehl-Strasburg-Arlington 1984, passim; Ph. T. Vegleris, Valeur et significatio de la clause ,dan une societé démocratique”dans la convention europeéne droits de l'homme, „Revue des Droits de l'Homme" 1968, s. 219-241. Trybunał Praw Człowieka w Strasburgu wyjątkowo tylko i w niektórych orzeczeniach stara się zdefiniować pojęcie ,społeczeństwa demokratycznego”. Czyni to m.in. w sprawie Handyside przeciwko Wielkiej Brytanii, gdzie w uzasadnieniu Trybunał stwierdził, że swoboda wypowiedzi jest jednym z filarów demokratycznego społeczeństwa - obok pluralizmu i tolerancji. Por. Hendyside przeciwko Wielkiej Brytanii - orzeczenie z 7 grudnia 1976 r., A. 24, zob. Europejski Trybunał Praw Człowieka, orzecznictwo, t. 2, Prawa do życia i inne prawa, oprac. M. A. Nowicki, Zakamycze 2002, s. 262-268. W kwestii ,społeczeństwa obywatelskiego”: por. A. B. Seligman, Komentarze o społeczeństwie obywatelskim i obywatelskiej cnocie w ostatniej dekadzie XX wieku, w: Ani ksiażę, ani kupiec: - obywatel, wybór tekstów i wstęp: J. Szacki, Kraków 1997, s. 195-198; B. Geremek, Społeczeństwo obywatelskie i współczesność, w: Europa i społeczeństwo obywatelskie. Rozmowy w Castel Gandolfo, Kraków 1994, s. 237; P. Ogrodziński, Pięć tekstów o społeczeństwie obywatelskim, Warszawa 1991, s. 70.

${ }^{23}$ Z. Kędzia, Uwagi o aksjologii Konstytucji, w: Prawa człowieka w społeczeństwie obywatelskim, red. A. Rzepliński, Warszawa 1993, s. 30. 
nych, może stać się przesłanką do uznania, że państwa takie należą do grupy demokratycznych państw prawa - byleby tylko istniała konstytucja, funkcjonowały w oparciu o przypisy prawa organy władzy ustawodawczej, wykonawczej i sądowniczej. Jeśli by zaakceptować takie założenie, wówczas okazałoby się - być może - że państwem prawa były zarówno hitlerowskie Niemcy, ZSRR, jak i Polska Rzeczypospolita Ludowa. Tak więc, z pełnym przekonaniem należy przeciwstawić się tezie, iż możliwe jest dowolne kształtowanie zasad aksjologicznych demokratycznego państwa prawnego, jak i twierdzeniu, że zasady takie są płynne, niejasne, niedoskonałe, czasowo zmienne oraz że mogą być dowolnie kształtowane przez grupy społeczne sprawujące aktualnie władzę. Nie oznacza to jednak, że system aksjologiczny państwa prawnego jest jedyny i niezmienny ${ }^{24}$. W literaturze dość stanowczo zauważa się, iż Konstytucja z 1997 r., będąc efektem kompromisu politycznego, odznacza się niespójnością aksjologiczną, a próby uporządkowania wartości, które legły u jej podstaw napotykają przeszkodę w postaci pluralizmu aksjologicznego ${ }^{25}$.

Demokratyczne państwo prawa to państwo, w którym każda jednostka, a nie tylko obywatel, lub niektóre kategorie obywateli mogą korzystać z praw i wolności, na straży których stoi państwo ze swoim aparatem. Jest to państwo, w którym każda mieszkająca w nim jednostka - a przede wszystkim obywatele (zwłaszcza ci, którzy posiadają zdolność do czynności prawnych i cieszący się pełnią praw) - czuje się odpowiedzialna za państwo. Reguły demokratycznego państwa prawnego w sensie materialnym zdają się nie ulegać wątpliwości. Należą do nich sprawiedliwość jurydyczna i społeczna, wolność oparta o ustawę zasadniczą, równość wobec prawa i oparcie kreacji organów o demokratyczne wybory, przy zagwarantowanym pluralizmie politycznym ${ }^{26}$. Dodać do tego należy często niezauważany w praktyce wymóg wolności środków społecznego przekazu, tolerancji religijnej, wolności kreacji artystycznej i badań naukowych. W znaczeniu formalnym, pojęcie państwa prawa oznacza, że działalność organów państwa opiera się na przepisach prawa (zasada legalności) oraz na podziale władz i ich wzajemnym hamowaniu się, a także zagwarantowaniu tego, iż ingerencja w sferę praw jednostki będzie możliwa tylko na mocy ustawy ${ }^{27}$. W doktrynie sformułowano dość dokładny katalog wolności i praw człowieka, których demokratyczne państwo prawa nie po-

\footnotetext{
${ }^{24}$ M. Kordela, Zarys typologii uzasadnień aksjologicznych $w$ orzecznictwie Trybunału Konstytucyjnego, Bydgoszcz-Poznań 2001, s. 273; tejże, Standardy rozstrzygnięć aksjologicznych, uwagi na tle orzecznictwa Trybunału Konstytucyjnego w latach 1998-2001, „,Gdańskie Studia Prawnicze” 2002, t. IX, s. 255 i n.; J. Mikołajewicz, Pojmowanie „państwa prawnego” w orzecznictwie Trybunału Konstytucyjnego, w: Polskie dyskusje..., s. 100 i n.

${ }^{25}$ J. Mikołajewicz, M. Smolak, Zasada demokratycznego..., s. 99. Trzeba zauważyć, że niespójność aksjologiczna Konstytucji wynika z jednej strony z pomieszania wartości liberalnych z chrześcijańskimi, z drugiej - z niespójności samej aksjologii chrześcijańskiej. Subiektywną i skrajnie jednostronną krytykę podstaw aksjologicznych konstytucji zaprezentował Ryszard Paradowski, zob. R. Paradowski, Konstytucja RP z 1997. Wartości podstawowe i zasady konstytucyjne, „Przegląd Religioznawczy” 2004, nr 4, s. 119 i n. Widzi on podstawowe zagrożenie dla demokracji w działaniu Kościoła katolickiego, który jego zdaniem zabiega o to, aby demokratyczne instytucje wypełnić niedemokratyczną treścią. Por. także: R. Paradowski, Kulturowe instrumentarium wolności, w: Kulturowe instrumentarium wolności. Etyka i prawo, red. R. Paradowski, Poznań 2005, s. 10. Wywody R. Paradowskiego mają charakter dość ogólnikowy, nie dotykają one warstwy jurydycznej.

${ }^{26}$ Państwo prawne w ujęciu materialnym realizuje określone wymagania treściowe i gwarantuje je poprzez związanie ustawodawcy normami konstytucyjnymi oraz regulacją praw i wolności obywatelskich. M. Wyrzykowski, Przepisy utrzymane w mocy. Przepisy konstytucyjne utrzymane w mocy przez art. 77 ustawy konstytucyjnej z dnia 17 października 1992, w: Komentarz do Konstytucji Rzeczypospolitej Polskiej, red. L. Garlicki, Warszawa 1995, komentarz do art. 1, s. 5. W kwestii państwa prawa w znaczeniu materialnym: K. Stern, Das Staatsrecht der BRD, t. I, München 1994, s. 775; B. Banaszak, Porównawcze prawo konstytucyjne współczesnych państw konstytucyjnych, Zakamycze 2004, s. 177.

${ }^{27}$ B. Banaszak, Prawo konstytucyjne, Warszawa 1999, s. 172.
} 
winno naruszać. Zaliczono do nich: prawo do godności i prywatności, prawo obywatelstwa, prawo do życia, prawo do równouprawnienia - niezależnie od płci, różnic narodowościowych, religijnych i językowych, prawo do małżeństwa, nienaruszalności mieszkania i korespondencji, prawo do wolności i bezpieczeństwa osobistego, wolność sumienia i wyznania, słowa i druku, zgromadzeń, zrzeszania się, prawo do życia w pokoju, prawo do posiadania własności, prawo do pracy i wynagrodzenia, prawo do odpowiedniego poziomu życia, zabezpieczenia społecznego, ochrony zdrowia, wypoczynku oraz nauki ${ }^{28}$. Na straży tych praw stoją akty prawa międzynarodowego, a w nich w pierwszym rzędzie: Powszechna Deklaracja Praw Człowieka (1948), Międzynarodowy Pakt Praw Obywatelskich i Politycznych (1966), Europejska Konwencja o Ochronie Praw Człowieka i Podstawowych Wolności (1950) oraz większość konstytucji.

Pojawia się w tym miejscu pytanie, czy państwo demokratyczne, państwo prawa może być darem jakiejś grupy społecznej lub politycznej, partii, stowarzyszenia, czy po prostu - aktem dobrodziejstwa sprawujących władzę. Wydaje się to niemożliwe, gdyż nie sposób narzucić ogółowi społeczeństwa systemu wartości demokratycznych warunkujących istnienie demokratycznego państwa prawa. W praktyce jednak tego rodzaju hasła są prezentowane, zazwyczaj w sposób akcentujący, iż dotychczasowe reguły funkcjonowania państwa są niedoskonałe, niejednoznaczne bądź błędne. Stąd też pojawiają się hasła przywrócenia w życiu społecznym i politycznym ,prawdziwej” bądź „,realnej” demokracji, ,prawdziwej” moralności. Głosząc takie tezy, rysuje się zwykle idee państwa prawnego jako złudny miraż, którego osiagnięcie realnie jest niemożliwe. W literaturze francuskiej podkreśla się przy tym, że państwo prawa musi oznaczać reguły generalne i ogólne. Tylko takie oznaczają bowiem poszanowanie dla równości prawa. Nie oznacza to jednak usunięcia wszelkiej władzy o charakterze dyskrecjonalnym i uznaniowym. Czyni się przy tym dystynkcje między państwem prawa a państwem legalnym. W państwie legalnym władza wykonawcza działa jedynie na podstawie ustawy, co oznacza, że nie ma reguł ograniczających ustawodawcę. W państwie prawa - różniącym się od państwa legalnego - władza ustawodawcza także związana jest regułami prawa $^{29}$. Tocząc spór o kształt katalogu nadrzędnych reguł wyznaczających granice państwa prawa, w literaturze nie podnosi się jednak wątpliwości co do tego, że należą do nich wszelkie zasady gwarantujące poszanowanie praw człowieka oraz zasada podziału władzy ${ }^{30}$. Zastrzeżenia budzi natomiast to, czy państwo prawa jest państwem sprawiedliwości społecznej czy państwem neoliberalizmu ekonomicznego bądź też państwem opatrznościowym (L'Etat Providence) ${ }^{31}$. W toczonych we Francji dyskusjach nad kształtem prawa zauważa się, iż życie społeczne i polityczne ulega nadmiernej ,jurydyzacji”, a rola sędziów i polityków w polityce niepokojąco wzrasta. Sytuacja ta odbierana jest jako niekorzystna, gdyż prowadzi do „władzy mędrców”32. Dlaczego

${ }^{28}$ L. Garlicki, Zasada równości, zakaz dyskryminacji w orzecznictwie TK, w: Obywatel, jego wolności i prawa, opr. B. Oliwa-Radzikowska, Warszawa 1998, s. 71; M. Gromadzka, O nowe spojrzenie na doktrynę liberalnego państwa prawnego, „Studia Nauk Politycznych” 1974, nr 2, s. 106; Konstytucje Rzeczypospolitej oraz komentarz do Konstytucja RP z 1997 roku, red. J. Boć, Wrocław 1998, s. 18-20; J. Oniszczuk, Konstytucja Rzeczypospolitej Polskiej w orzecznictwie Trybunatu Konstytucyjnego na poczatku XXI w., Zakamycze 2004, s. 195-200.

${ }^{29}$ J. Chevalier, L' Etat de droit, ,Revue du droit public et de la science politique en France at á l'étranger”, t. CIV, Mars-Avril 1988, z. 2, s. 131 i n..

${ }^{30}$ B. Berret-Kriegel, Etat de droit, w: Dictionnaire constitutionell, red. O. Duhamel, Y. Mény, Paris 1992, s. 418; tejże, L'Etat et ses esclaves. Reflexions pour l'histoire des Etat, Editions Payot, Paris 1989, s. 33.

${ }^{31}$ Zob. Libéralisme et Etat de droit. Actes du Colloques, „Libéralisme et Etat de Droit”, red. J. Bidet, G. Labica, Paris 1992, passim.

${ }^{32}$ B. François, Justice constitutoinnelle et ,, démocratie connstitutionelle”. Critique du discours constitutionnaliste europeén, „Droits et Politique”, PUF, Paris 1993, s. 53-64. 
jednak „władza mędrców” miałaby być zagrożeniem zwykle się nie wyjaśnia. Podkreśla się jednak, i to dość stanowczo, że demokracja nie może być pojmowana jako dyktatura większości, a jednostki muszą mieć prawne gwarancje posiadanych wolności ${ }^{33}$. Akcentuje się, iż państwo prawa jest wartością ważniejszą niż demokracja, której zresztą nie neguje, jako że stanowi jej podstawę ${ }^{34}$. Warto odnotować, iż taką obawę przed sądami, zwłaszcza naprawdę niezawisłymi sądami i trybunałami prezentują także niektórzy polscy politycy, a wraz z nimi - niektórzy publicyści.

Kwestionowanie koncepcji państwa prawa następuje nader często nie wprost, lecz pod pozorem reorientacji zasad moralnych, ,powrotu do korzeni”, przywrócenia ,,prawdziwego systemu wartości”. Postulując konieczność reorientacji systemu aksjologicznego, zwolennicy takich koncepcji powołują się na swoiście rozumianą suwerenność parlamentu, twierdząc najczęściej, że wola większości w akcie wyborczym pozwala im nie tylko swobodnie reformować model ustrojowy ${ }^{35}$, lecz także - zakwestionować niezależność wszelkich innych władz, w tym zwłaszcza sądowniczej i kontrolnej. Prowadzi to bezpośrednio do zakwestionowania zasady podziału władzy, wzajemnego kontrolowania się i hamowania poszczególnych władz oraz do zakwestionowania roli organów stojących na straży zgodności norm prawnych z konstytucją ${ }^{36}$. Tego rodzaju argumenty prezentowali w przeszłości zwolennicy modelu państwa faszystowskiego, po demokratycznym przecież dojściu Hitlera do władzy. Nie sposób utożsamiać przestrzegania prawa przez organy państwowe i obywateli z funkcjonowaniem państwa prawa. Zresztą, wyraźnie daje się zauważyć, iż demokracja konstytucyjna różni się - i to jaskrawo - od demokracji ,,większościowej”. W demokratycznym państwie prawa przekonania moralne piastunów władzy publicznej nie mogą ograniczać sfery wolności ${ }^{37}$.

Doświadczenia reżimów autorytarnych, a wśród nich w pierwszym rzędzie - totalitarnych, spowodowały po II wojnie światowej gwałtowne poszukiwanie gwarancji chroniących jednostkę przed trudnymi do przewidzenia działaniami władzy państwowej. Stąd właśnie pojawiające się wówczas - przede wszystkim na forum międzynarodowym - regulacje, mające na celu sformułowanie niezbywalnych praw przyrodzonych jednostce ludzkiej, których żadna władza nie może kwestionować bądź naruszać. Do tego sprowadza się podmiotowa uniwersalność praw człowieka ${ }^{38}$. Natomiast przedmiotowa uniwersalność ich zasadza się na

\footnotetext{
${ }^{33}$ Pogłębioną analizę francuskich sporów dotyczących koncepcji państwa prawa przedstawiła Maria Zmierczak w erudycyjnym artykule Współczesna dyskusja nad pojęciem państwa prawa we Francji, w: Studia z historii państwa, prawa i idei. Prace dedykowane Profesorowi Janowi Malarczykowi, red. A. Korobowicz, H. Olszewski, Lublin 1997, s. 501-511.

${ }^{34}$ C. Goyard, Etat de droit et démocratie, w: Mélanges René Chapus. Droit administratif, Montchrestien, Paris 1992, s. 300-301.

${ }^{35}$ Warto zauważyć, ze Europejski Trybunał Praw Człowieka w Strasburgu stwierdził niegdyś - rozstrzygając drobną w istocie sprawę - że jakkolwiek interesy jednostki muszą być czasami podporządkowane interesom grupowym, to jednak demokracja nie oznacza, że poglądy większości zawsze mają przewagę. Zob., Chassagnou i inni przeciwko Francji - orzeczenie z 29 kwietnia 1999 r., Wielka Izba, raporty Europejskiej Komisji Praw Człowieka z 30 października 1997 r., skargi nr 25088/94, 28331/95, 28443/95, w: Nowy Europejski Trybunał Praw Człowieka. Wybór orzeczeń 1999-2004, oprac. M. A. Nowicki, Zakamycze 2005, s. 1177-1181.

${ }^{36}$ M. Wyrzykowski, Współczesne przemiany w postrzeganiu standardów demokratycznego państwa prawnego (Siedem grzechów, siedem cnót), w: Prawo a polityka, red. M. Zubik, Warszawa 2007, s. 35-57.

${ }^{37}$ M. Safjan, Państwo a wartości etyczne, ibidem, s. 24 i n.

${ }^{38}$ Podkreśla się, że niepodzielność praw człowieka i ich współzależność zasadza się na tym, że niemożliwe jest łamanie innych praw, aby przestrzegać innych. Może się natomiast zdarzyć, iż w państwie przestrzegać się będzie jednego prawa łamiąc pozostałe. J. Morisink, The Universal Declaration of Human Rights: origins, drafting, and intent, University of Pennsylvanian Press, Filadelfia 1999, passim; także, Cultural genocide, The Universal Declaration of minority rights, „Human Rights Quarterly” 1999, nr 21 (4), s. 1009-1060.
} 
różnych jego potrzebach, wynikających, jak się najczęściej przyjmuje: z przyrodzonej godności ${ }^{39}$. Prawa takie to prawa polityczne, obywatelskie, gospodarcze, socjalne i kulturalne - uniwersalne terytorialnie, znajdujące gwarancje i potwierdzenie w umowach międzynarodowych, deklaracjach organizacji międzynarodowych oraz w konstytucjach i ustawach poszczególnych państw ${ }^{40}$. Począwszy od drugiej połowy lat czterdziestych XX wieku, aż po schyłek tegoż stulecia, prawa człowieka stanowiły niepodważalny punkt wszelkich dyskursów politycznych, w trakcie których spierano się co najwyżej o treść tych praw oraz o gwarancje dla nich ${ }^{41}$. Samo istnienie wolności i praw człowieka wydawało się niepowtarzalne - i to tak dalece, że nie poddawał ich istnienia w wątpliwość ani b. ZSRR, ani satelickie państwa tzw. bloku wschodniego - aczkolwiek, deklaracje o treści owych praw miały w gruncie rzeczy w tych państwach charakter semantyczny, a systemy prawne w nich istniejące nie przewidywały ani gwarancji ochrony na odpowiednio wysokim poziomie, ani możliwości ich dochodzenia. Dokonana po II wojnie światowej - najpierw przez ONZ, a potem przez oba systemy europejskie - instytualizacja praw człowieka spowodowała, iż mogą być one rozumiane w kategoriach socjologicznych jako globalna ideologia. I rzeczywiście - w dużej mierze mają one taki charakter ${ }^{42}$. Do momentu przyjęcia przez ONZ Powszechnej Deklaracji Praw Człowieka, a potem Międzynarodowego Paktu Praw Obywatelskich i Politycznych, miały one charakter w gruncie rzeczy metafizyczny i naturalny. Źródeł ich doszukiwano się także w naturze, już ukształtowanej przez kulturę oraz w uniwersalnych zasadach moralnych rodzaju ludzkiego. Zauważyć tu wypada, że samo pojęcie takich zasad w praktyce jest dość sporne $^{43}$. Niektórzy gotowi byli wyjaśniać pochodzenie praw człowieka, jako dyktat naturalnego rozumu, co w skrajnych przypadkach musiało prowadzić do nieuchronnej subiektywizacji tych praw. Wielu widziało także prawa naturalne jako dar Boga. Koncepcji tej hołdowali wyraźnie pobożni Amerykanie w Deklaracji Niepodległości. Bliska jest ona także niektórym nurtom współczesnego islamu. Próbą pogodzenia tych rozbieżności jest uznanie, że źródłem praw człowieka jest godność ludzka. Jakkolwiek, co do jej treści istnieje dość szeroki konsensus, to jednak zgodzić się należy, że jest to termin niedookreślony. Trudności te pogłębia fakt, że po II wojnie światowej rozbudowano prawa człowieka drugiej generacji, społeczne i ekonomiczne - takie jak prawo do pracy, edukacji, opieki lekarskiej itd. Prawa te w gruncie rzeczy mogą być realizowane jedynie w społecznościach przemysłowych bądź poprzemysłowych i stanowią ciągle jeszcze nieosiaggalny cel w większości krajów Afryki i Azji ${ }^{44}$. Realizacja niektórych praw człowieka wydaje się możliwa we wszystkich systemach politycznych, niezależnie od ich charakteru. Cały ich zespół może być zrealizowany wyłącznie w ramach demokratycznego państwa prawa.

\footnotetext{
${ }^{39}$ E. Brems, Human Rights: Universality and Diversity, The Hague-Boston-London 2001, passim; T. Triggs, Morality Matters, Blackwell Publishing 2005, s. 135.

${ }^{40} \mathrm{M}$. Waters, Human rights and the universalisation of interests:towards a social constructionists approach, „Sociology” 1996, nr 30 (3), s. 593-600.

${ }^{41}$ J. Habermas, Zur Legitymisation durch Menschenrechte, w: Das Recht der Republik, red. P. Nielsen, Frankfurt am Main 1999, s. 386. Por. także tegoż, Faktyczność i obowiazywanie. Teoria dyskursu wobec zagadnień prawa i demokratycznego porzqdku prawnego, Warszawa 2005, s. 101-104, 137-146, 148 i n.

42 J. Donelly, Universal Human Rights in Theoryb and Practice, Cornell University Press, Itaca, NY 1989, s. 223,

${ }^{43}$ B. S. Turner, Outlineof a theory of human rights, ,Sociology” 1993, nr 27 (3), s. 489-512; tegoż, Introduction: rights and communities: prolegomenon to a sociology of rights, ,Australian and New Zealand Journal of Sociology” 1995, nr 31 (2), s. 1-8.

${ }_{44}$ J. Baszkiewicz, Filozoficzne i praktyczne dylematy..., s. 49-62.
} $227-228$. 
Procesy globalizacyjne końca XX wieku wyraźnie zmuszają do zastanowienia się nad tym, jaki jest stosunek praw człowieka do praw obywatelskich, zważywszy, że te drugie warunkowane są przez zjawiska o charakterze socjologicznym i politologicznym, takie jak: migracja, uchodźstwo, bieda oraz bezrobocie ${ }^{45}$.

W płaszczyźnie międzynarodowej prawa człowieka leżą u podstaw całego prawa humanitarnego i humanitarnych interwencji ${ }^{46}$. Realizacja ich może - co paradoksalne - prowadzić do kulturowego imperializmu, aczkolwiek międzynarodowe instytucje stojące na straży praw człowieka i monitorujące ich przestrzeganie dość powszechnie akceptują zasadę, że standardy praw człowieka winny być interpretowane rozmaicie w różnych kontekstach kulturowych $^{47}$. Warto zauważyć, że uniwersalizm praw człowieka krytykowany jest jako przejaw odrzucanego liberalizmu przez tzw. fillozofię komunitariańską, co wiąże się z negacją liberalno-demokratycznej sprawiedliwości i liberalnej demokracji ${ }^{48}$.

W demokratycznym państwie prawa nie może być mowy o łamaniu praw człowieka, ani nawet o taktycznych ustępstwach i przyzwoleniach na takie działania. W praktyce, rządy w takich państwach akceptują prawa człowieka, a nawet usiłująje wdrożyć w życie. Niemniej i w takich państwach dochodzi do naruszeń praw człowieka, gdyż - jak zauważa się w literaturze - dopiero długotrwałe ich istnienie $\mathrm{w}$ ramach systemu prawnego powoduje akceptację ze strony rządzących i praktyczne wcielanie w życie ${ }^{49}$. Przestrzeganie praw człowieka w dużej mierze zależy od siły i wpływów organizacji pozarządowych działających w danym państwie $^{50}$. Mimo wszystko jednak, w literaturze podnosi się, iż państwa - nawet te, mające charakter demokratycznych państw prawa - niechętnie postrzegają naciski w zakresie przestrzegania tych praw, zarówno wywodzące się z kręgu społeczności danego państwa, jak i spoza jego granic ${ }^{51}$. Istotnym problemem dla praw człowieka stały się konsekwencje zamachów terrorystycznych z dnia 11 września 2001 roku. Nieprzewidzianym przez terrorystów skutkiem ich działania okazało się powstanie klimatu społecznego przyzwolenia dla postępowania organów państwowych ograniczających prawa człowieka i obywatela. Najpierw administracji Stanów Zjednoczonych, a następnie rządom licznych państw europejskich udało się, przy wykorzystaniu haseł konieczności zwalczania terroryzmu, uzyskać akceptację społeczną dla działań naruszających godność i prywatność - godzących w ochronę danych

${ }^{45}$ N. Stammers, Social movements and the socialconstruction of human rights, „Human Rights Quarterly”1999, nr 21 (4), s. 980-1008.

46 J. Zajadło, Dylematy humanitarnej interwencji. Historia - Etyka - Prawo, Gdańsk 2005, s. 9-19, 42-50, 189-204; F. Abiew, The Evolution of the Doctrine and Practice of Human Intervention, The Hague-Boston-London 1999, s. 83-90.

${ }^{47}$ A. H. Robertson, J. G. Merrills, Human Rights in the World: an introduction to the studyof the international protection of human rghts, Manchester 1996, s. 64; Y. Arai, The margin of appreciation doctrine in juriprudence of Article 8 of the European Convention of Human Rights, „Netherlands Quartrly of Human Rights” 1998, nr 16 (1), s. $41-61$.

48 J. Waldron, Nonsense Upon Stils: Bentham, Burke, Marz on the Rights of Man, London 1987, s. 151, 166-209; S. Mulhall, A. Swift, Liberals and Commutarians, wyd. 2, Oxford 1996, passim.

${ }^{49}$ T. Risse, S. C. Ropp, International human rights norms and domestic change: conclusion, w: The Power of Human Rights: international norms and domestic change, red. T. Risse, S. C. Ropp, K. Sikking, Cambridge 1999 , s. $234-278$.

${ }^{50}$ R. P. Claude, B. H. Weston, International human rights: overview, w: Human Rights in the/world Community: issues and action, red. P. Claude, B. H. Weston, wyd. 2, Filadelfia, s. 1-14; P. R. Baehr, Human Rights: universality in practice, Macmillan, Basing-Stoke 1999, s. 114, 126-127; D. P. Forsythe, Human Rights in International Relations, Cambridge 2000 s. 173-177.

${ }^{51}$ J. Foweraker, T. Landman, Citenship Rights and Social Movements: a comparative and statistical analysis, Oxford 1997, passim. 
osobowych i prawo do informacji, tajemnicy korespondencji, wolności słowa, zgromadzeń, zrzeszania się ${ }^{52}$. Społecznym konsensusem objęte zostało także łamanie prawa do sądu, prawa człowieka podejrzanego bądź oskarżonego o popełnienie przestępstwa ${ }^{53}$, nie wspominając już o prawach więźnia ${ }^{54}$. Demokratyczne społeczeństwa Zachodu, żyjące w realnych demokratycznych państwach prawa, wiedzione strachem zaakceptowały nawet naruszenia takich praw jak: zakaz stosowania tortur i innego nieludzkiego traktowania ${ }^{55}$, nie mówiąc już o zasadzie równości, niedyskryminacji, prawie do posiadania obywatelstwa. Jakże inaczej wytłumaczyć utrzymującą się akceptację istnienia nieludzkiego obozu koncentracyjnego w Guantanamo i brak protestów na wieść o stosowanych tam bestialskich torturach? Syte społeczeństwa państw - mieniących się demokratycznymi państwami prawa - za cenę złudnego spokoju i ochrony przed - chyba jednak mało realną - groźbą ataku terrorystycznego gotowe są niezwykle łatwo zaakceptować odejście od standardów praw człowieka, nie bacząc

${ }^{52}$ Rozważając warunki zgodności systemów tajnej kontroli z art. 8 Europejskiej Konwencji o Ochronie Praw Człowieka i Podstawowych Wolności, Europejski Trybunał Praw Człowieka w Strasburgu podkreślił, iż muszą się one wiązać z odpowiednimi zabezpieczeniami prawnymi, a procedury nadzoru nad działalnością tajnych służb powinny możliwie jak najbardziej odpowiadać wartościom demokratycznych społeczeństw, a zwłaszcza zasadzie rządów prawa (Warto odnotować, iż Trybunał nie posłużył się terminem „,państwo prawa”, a z treści orzeczenia wynika, że stawiał między tymi określeniami znak równości). Zdaniem Trybunału, wyrafinowana i coraz powszechniej dostępna technika i technologia budzi nowe wyzwania w sferze rejestrowania rozmów i innych form komunikowania się oraz ochrony danych osobowych. Prawo regulujące taką kontrolę musi być wyjątkowo precyzyjne, a reguły w nim sformułowane - jasne i szczegółowe, przy czym każda faza stosowania środków kontroli lub przetwarzania danych winna być szczegółowo uregulowana. Trybunał zauważył, iż istnieje potrzeba gwarancji dla osób będących w pewnym sensie przypadkowymi uczestnikami podsłuchiwanych rozmów (np. telefonicznych), wówczas gdy obiektem kontroli jest ktoś inny. Zdaniem Trybunału, zbyt często zapomina się o obowiązku poszanowania praw takich osób ,przypadkowych” w co najmniej takim stopniu, jak osób, wobec których zarządzono podsłuch. Zaakcentował także, że gromadzenie przez władze publiczne danych o jednostce jest ingerencją w prawo do poszanowania życia prywatnego. Zob. Amann przeciwko Szwajcarii, orzeczenie z 16 lutego 2000 r., Wielka Izba, raport Europejskiej Komisji Praw Człowieka z 20 maja 1998 r., skarga nr 27798/95, w: Nowy Europejski..., oprac. M. A. Nowicki, s. 781-785; Rotaru przeciwko Rumunii - orzeczenie z 4 maja 2000 r., Wielka Izba, raport Europejskiej Komisji Praw Człowieka z 1 marca 1999 r., skarga nr 28341/95, ibidem, s. 793-797.

53 Trybunał nie zaakceptował podstępu, ani wprowadzania w błąd w celu ułatwienia aresztowania osób podejrzanych, stwierdzając, że jakkolwiek poważnym problemem są przestępstwa terrorystyczne, to jednak nie usprawiedliwiają one zatrzymywania i przetrzymywania w aresztach policyjnych podejrzanych bez jakiejkolwiek skutecznej kontroli sądowej w sytuacji, gdy organy tego państwa uważają, że mają do czynienia z przestępstwem terrorystycznym. Trybunał podkreślił, że walcząc $z$ terroryzmem państwo musi przedstawić przynajmniej niektóre fakty lub informacje, mogące przekonać obiektywnego obserwatora, że zatrzymany był w uzasadnionym stopniu podejrzany o popełnienie przestępstwa. Zob., O’Hara przeciwko Wielkiej Brytanii - orzeczenie z 16 października 2002 r., Izba (Sekcja III), skarga nr 37555/97, w: Nowy Europejski Trybunat Praw Człowieka. Wybór orzeczeń 1999-2004, oprac. M. A. Nowicki, Zakamycze 2005, s. 266-269; także Conca przeciwko Belgii - orzeczenie z 5 lutego 2002 r., Izba (Sekcja III), skarga nr 51564/99, ibidem, s. 269-274.

${ }^{54}$ E. Kustra, Granice ingerencji państwa w prawo do prywatności w świetle orzecznictwa Europejskiego Trybunału Praw Człowieka w Strasburgu, w: Społeczeństwo inwigilowane w państwie prawa, red. P. Chrzczonowicz, V. Kwiatkowska-Darul, K. Skowroński, Toruń 2003, s. 17-24.

${ }^{55}$ Dzieje się to jednak przy absolutnym braku przyzwolenia ze strony stojącego na straży praw człowieka Trybunału w Strasburgu, który stanowczo podkreśla w licznych orzeczeniach, że z torturami mamy do czynienia wówczas, gdy chodzi o wymuszenie w ten sposób informacji, ukaranie bądź zastraszenie. Zob.: Dicme przeciwko Turcji-orzeczenie z 11 lipca 2000 r., Izba (Sekcja I), skarga nr 20869/92, w: Nowy Europejski Trybunat Praw Człowieka. Wybór orzeczeń 1999-2004, oprac. M. A. Nowicki, Zakamycze 2005, s. 236-242. Trybunał podkreślił, że niektóre zachowania dotychczasowo uważane za nieludzkie i poniżające traktowanie, a nie tortury, w przyszłości mogą być kwalifikowane surowiej. Podkreślając, że rosnące wymagania w sferze ochrony praw człowieka i podstawowych wolności prowadzą nieuchronnie do coraz surowszej oceny zamachów na podstawowe wartości społeczeństw demokratycznych, zob. Hénav przeciwko Francji, orzeczenie z 27 listopada 2003, Izba (Sekcja I), skarga nr 65436/01, w: Nowy Europejski..., oprac. M. A. Nowicki, s. 302-305. 
na to, że złamanie ich stanowi jednocześnie przekreślenie całej koncepcji demokratycznego państwa prawa $^{56}$. Daleko posunięta kontrola społeczna, inwigilacja obywateli - nawet połączona z naruszeniem prawa do prywatności, nienaruszalności mieszkania i tajemnicy korespondencji, zdaje się leżeć w interesie rządów państw asygnujących olbrzymie kwoty na skomplikowane technicznie programy pozwalające na ziszczenie się orwellowskiej wizji „Wielkiego Brata"57. Postawie tej sprzyja nie tylko globalizacja ${ }^{58}$, lecz także zmiany techniczne, umożliwiające powstanie społeczeństwa informacyjnego ${ }^{59}$. W państwach daleko

${ }^{56} \mathrm{~W}$ praktyce Trybunału brak zgody na tego typu ogląd rzeczywistości, wręcz przeciwnie - w licznych orzeczeniach Trybunał podkreślał niezwykłe znaczenia zasady pewności prawnej, będącej niezbędnym warunkiem poszanowania rządów prawa - wspólnego dziedzictwa państw Konwencji. Jednocześnie podkreślał, że pluralizm i demokracja oparte są na kompromisie wymagającym ustępstw ze strony jednostek, które zmuszone są zaakceptować ograniczenia niektórych wolności, aby w ten sposób zagwarantować większą stabilizację kraju. Zawsze jednak w takiej sytuacji państwo ma obowiązek starannego rozważenia zakresu takich ograniczeń i ich skutków. Trybunał, rozwijając ideę, ,demokracji zdolnej do obrony”, zauważył, że stabilność i skuteczność systemu demokratycznego może w pewnych sytuacjach wymagać podejmowania przez państwo konkretnych działań w celu obrony demokracji. Orzeczenie Refah Partisi i inni przeciwko Turcji z 13 lutego 2003 r., Wielka Izba, skarga nr 41340/98, 41342/98, 41343/98, w: Nowy Europejski..., oprac. M. A. Nowicki, s. 302-305.

57 Trybunał w Strasburgu wyraźnie stwierdził, że w demokratycznym społeczeństwie opartym na rządach prawa należy umożliwić pokojowe wyrażanie politycznych idei kwestionujących istniejący porządek w drodze korzystania z prawa do zgromadzeń, lub przy pomocy innych metod. Środki ograniczające swobodę takich zgromadzeń, niezależnie od tego jak szokujące lub nie do zaakceptowania dla władz mogą być poglądy uczestników takich zgromadzeń, nie służą demokracji, a wręcz przeciwnie - często jej zagrażają. Swoboda zgromadzeń zagwarantowana w art. $11 \mathrm{Eu}-$ ropejskiej Konwencji o Ochronie Praw Człowieka i Podstawowych Wolności chroni demonstrację, która może irytować lub dotykać osoby sprzeciwiające się głoszonym przez demonstrantów ideom lub żądaniom. Zob. Stankow i Zjednoczona Macedońska Organizacja Iliden (United Macedonian Organisation Iliden) przeciwko Bułgarii, orzeczenie z 2 października 2001 r., Izba (Sekcja I), skarga nr 29225/95 i 29221/95, w: Nowy Europejski..., oprac. M. A. Nowicki, s. 1134-1139.

58 Przegląd definicji pojęcia ,globalizacja” i próbę ich systematyzacji przynosi praca K. Gilarek, Państwo narodowe a globalizacja - dynamika powstawania nowego ładu, Toruń 2003, s. 39-46; W. Anioł, Geneza i rozwój procesów globalizacji, Warszawa 1989, passim; Z. Bauman, Globalizacja, Warszawa 2000, s. 5-10. Termin ,globalizacja”, jak przyjmuje się w literaturze, najprawdopodobniej pojawił się po raz pierwszy w słowniku Webstera z 1961 r. Według R. Kilminstera jest to moment, od którego zaczęto w nauce dostrzegać, iż wydarzenia polityczne i militarne oraz relacje społeczne mają ciągle wzrastające znaczenie nie tylko dla obszaru, na którym zaistniały, lecz także w skali całego globu. N. Stammers, Social movements and the challenge to power, w: Politics in Globalized Word, red. M. Shaw, London 1999, s. 73 i n.; J. A. Scholte, The Globalization of World Politics, w: The Globalization of World Politics. An Introduction to International Relations, red. J. Baylis, S. Smith, New York 2001, s. 23; tenże, Globalization: prospects for a paradigm shift, w: Politics in Globalized..., s. 9 i n.; I. Clark, Globalization and International Relation Theory, Oxford 1999, s. 35. Stanowiska prezentowane w literaturze naukowej dotyczące istoty i zakresu procesów globalizacji w kompetentny i przejrzysty sposób przedstawił M. Pietras w artykule Globalizacja jako proces zmiany społeczności międzynarodowej, w: Oblicza procesów globalizacji, red. M. Pietras, Lublin 2002, s. 36-50. W kwestii globalizacji kultury por. m.in. H. P. Martin, H. Schumann, Pułapka globalizacji, Wrocław 1999, s. 20 i n.; P. Starosta, Globalizacja i nowy komunitaryzm, „Kultura i Społeczeństwo” 2000, t. XLIV, nr 3, s. 47; A. Kozłowska, Kultury narodowe wobec globalizacji a tożsamość jednostki, „Kultura i Społeczeństwo” 1997, nr 4, s. 4. W kwestii animozji między USA a państwami Unii Europejskiej zob. m.in. F. Bergsten, America and Europe: Clash of the Titans?, „Foreign Affairs” 1999, nr 2; Guliwer i lilipuci. Rozmowa z Aleksandrem Smolarem, „Gazeta Wyborcza” z 28-29 września 2002 r.; D. de Villepin, W nowym świecie nowy lad, „Gazeta Wyborcza” z 21-22 września 2002 r.; A. Jarczewska-Romaniuk, Unia Europejska a idea transatlantycka-partnerstwo transatlantyckie w progu nowego wieku, w: Unia europejska. Nowy typ wspólnoty międzynarodowej, red. E. Haliżak, S. Parzymięs, Warszawa 2002, s. 276-298; Z. Brzeziński, Supermocarstwo UE a Stany Zjednoczone, „Rocznik Strategiczny” 2000/2001, s. 22 i n.; D. Czerny, Stany Zjednoczone i Europa - nowe wyzwania, w: Stosunki międzynarodowe w Europie na przełomie XX i XXI wieku. Wybrane aspekty, red. J. Przewłocki, M. Stolarczyk, Katowice 2002, s. 9-18; S. Bieleń, Przywództwo globalne Stanów Zjednoczonych Ameryki, w: Prawo, instytucje i polityka w procesie globalizacji. Księga jubileuszowa dedykowana profesorowi Januszowi Symonidesowi, red. E. Haliżak, R. Kuźniar, Warszawa 2003, s. 401 i n.

${ }^{59}$ W kwestii społeczeństwa informacyjnego por., np. O nowy ład międzynarodowy. Raport dla Klubu Rzymskiego, red. J. Tinbergen, Warszawa 1978. Przyznać jednak należy, że zarówno pod koniec lat siedemdziesiątych, jak 
mniej narażonych na rzekome zagrożenia aparat propagandowy wykorzystując rzekomo wolne i niezależne środki społecznego przekazu, stające się w poszukiwaniu sensacji tubą rządzących tworzy atmosferę lęku i zagrożenia atakiem terrorystycznym. Tam, gdzie zaistnienie jego wydaje się mało prawdopodobne, wykorzystywany jest jako podstawa do wprowadzenia ograniczeń praw człowieka rzekomy brak bezpieczeństwa obywateli. Mieszkańcy akceptować przy tym są gotowi widowiskowe akcje zatrzymań osób podejrzanych, nie zastanawiając się nad tym, że obrazy te dokumentują naruszanie praw człowieka. Sytuacje te sprzyjają także przyzwoleniu na wszelkie działania organów państwowych, w szczególności tzw. służb tajnych i specjalnych na powszechne stosowanie podsłuchu, inwigilacji, mniej lub bardziej brutalne przeszukania mieszkań ${ }^{60}$. W społeczeństwach mieniących się ,demokratycznymi” znaczące grupy nie widzą nic złego w prześladowaniu ,innych” - różniących się kolorem skóry, religią bądź orientacją seksualną. Gotowe są zaakceptować przeszukiwanie prywatnych bibliotek w poszukiwaniu pornografii, prywatną cenzurę i inwigilację połączeń internetowych jako panaceum na domniemane lub rzeczywiste zagrożenie pedofilia, łamanie wolności sumienia i wyznania pod pozorem ochrony przed zgubnym wpływem sekt ${ }^{61}$, wresz-

i w latach osiemdziesiątych publikowano prace o „nowym międzynarodowym ładzie”, zob. np. M. Szulczewski, Koncepcja nowego międzynarodowego tadu informacyjnego, „Sprawy Międzynarodowe” 1978, nr 10; J. Pastecka, System informacji a nowy międzynarodowy ład ekonomiczny, w: Nowy międzynarodowy ład ekonomiczny, red. P. Bożyk, Warszawa 1989, s. 98, ale już K. Jakubowski przestawia szyk wyrazów i pisze artykuł: O nowy ład międzynarodowy w dziedzinie komunikowania masowego, „Przekazy i Opinie” 1980, nr 1. Warto zauważyć, że obok sporu o przymiotniki: ,światowy” i ,międzynarodowy” w odniesieniu do nowego ładu jeszcze istotniejszy i donioślejszy ideologicznie był spór o terminy: „środki komunikowania masowego”, „środki masowej informacji”. W kwestii tej por. J. Sobczak, Prawo prasowe. Podręcznik akademicki, Warszawa 2000, s. 74 i n. Przykładem może być Raport Końcowy Międzynarodowej Komisji do Badania Problemów Komunikowania (International Commission for the Study of Communication Problems), czyli tzw. Komisji Mac Bride'a. Por. International Commission for the Study of Communication Problems. Final Report, UNESCO Press, Paris 1979.

${ }^{60}$ Europejski Trybunał w Strasburgu podkreślił, że tajne środki kontroli stanowią szczególne zagrożenie dla prawa do poszanowania korespondencji. Jest ona wprawdzie dopuszczalna, ale musi mieć charakter wyjątkowy, podlegać określonym procedurom, których treść ma być jasna i szczegółowa. Zdefiniowane w niej winny być kategorie osób, wobec których można stosować podsłuch, rodzaj przestępstw, w związku z którymi można wydać stosowne zezwolenie oraz kwestie dotyczące przechowywania i niszczenia takowych zapisów. Zob., Klass przeciwko Niemcy - orzeczenie z dnia 6 września 1978 r., A. 28; raport Europejskiej Konwencji Praw Człowieka z 9 marca 1977 r., skarga nr 5029/71, w: Europejski Trybunał..., oprac. M. A. Nowicki, t. 2, s. 812-818. W treści wspomnianego orzeczenia Trybunał zauważył, że fakt, zagrożenia społeczeństw demokratycznych bardzo wyrafinowanymi formami szpiegostwa i terroryzmu, zmusza państwa do tajnej kontroli podejrzewanych o taką działalność. W tym zakresie państwa korzystają z pewnej swobody przy ustalaniu rodzaju i sposobu użycia środków inwigilacji. Nie oznacza to jednak, że mogą korzystać z nich całkowicie dowolnie. Na tle sprawy Kruslin przeciwko Francji - orzeczenie z 24 kwietnia 1990 r., A. 176-A; raport Europejskiej Konwencji Praw Człowieka z 14 grudnia 1988 r., skarga nr 11801/85, w: Europejski Trybunał..., oprac. M. A. Nowicki, t. 2, s. 834-838. Trybunał stwierdził, iż podsłuch i inne formy kontroli rozmów telefonicznych są poważną ingerencją w życie prywatne i korespondencję, a więc muszą mieć wyjątkowo precyzyjną podstawę w prawie. Por. też, uwagi w przypisie 56.

${ }^{61} \mathrm{~W}$ przedmiocie sekt, por., E. M. Guzik-Makaruk, Sekty religijne w Polsce, Warszawa 2004, szczególnie s. 19-50; M. Szostak, Sekty destrukcyjne. Studium metodologiczno-kryminalistyczne, Zakamycze 2001, s. 25-128. Pojęciem ,sekta” nie posługuje się żaden z polskich aktów normatywnych. Odnajdziemy je jedynie w materiałach Nadzwyczajnej Komisji ds. Grup Psychomanipulacyjnych Komisji Rodziny Sejmu RP oraz Międzyresortowego Zespołu ds. Nowych Ruchów Religijnych. Używanie terminu „,sekta” w publicystyce oraz wypowiedziach politycznych w odniesieniu do zarejestrowanych związków wyznaniowych jest nieuprawnione i ma częstokroć głęboko pejoratywny charakter, stając się przejawem tzw. religijnego i kulturalnego imperializmu. Europejski Trybunał Praw Człowieka dokonując wykładni art. 9 Europejskiej Konwencji o Ochronie Praw Człowieka i Podstawowych Wartości jednoznacznie stwierdził, że prawo do swobody wyznania obejmuje oczekiwanie, że wspólnota religijna będzie mogła spokojnie działać, wolna od arbitralnych ingerencji państwa. Stwierdził także, że z wyjątkiem przypadków bardzo szczególnych, prawo wolności religii wyklucza wszelką swobodę państwa w ocenie czy przekonania religijne lub środki użyte do jej wyrażenia są uprawnione. Państwo ma obowiązek zachować bezstronność w stosunkach 
cie - gwałcenie tajemnicy bankowej ${ }^{62}$, po to by przeciwdziałać podejrzeniom o pranie brudnych pieniędzy, naruszanie tajemnicy korespondencji, kontrole rozmów telefonicznych jako źródła informacji o nielegalnych działaniach przestępców ${ }^{63}$. Stworzenie obrazu zagrożenia pozwala na łatwe manipulowanie opinią publiczną, na odwracanie jej uwagi od rzeczywistych problemów poprzez wskazywanie ciagle nowych zagrożeń i nowych wrogów.

W tej sytuacji, rządzącym dość łatwo już negować potrzebę przestrzegania praw drugiej generacji, wśród nich zaś prawa do pracy, godziwego wynagrodzenia, prawa do wypoczynku, do zabezpieczenia społecznego, do nauki, udziału w życiu kulturalnym bądź prawa do nieskażonego środowiska dla obecnego i następnych pokoleń. Nieistotne są przy tym argumenty i mniej lub bardziej racjonalne przesłanki, leżące u podstaw negowanych praw.

Tej w gruncie rzeczy zasmucającej sytuacji towarzyszą także inne trudności związane z wcielaniem w życie koncepcji państwa prawa. Wśród nich wskazać należy powszechną tendencję do ukrywania przez państwa składające sprawozdania z realizacji Paktów Praw Człowieka faktów, które mogłyby spotkać się z negatywną oceną ze strony międzynarodowych organów kontrolnych. Brak także w większości państw działań o charakterze edukacyjnym, informujących społeczeństwo o treści praw człowieka ${ }^{64}$. Efektem jest nieznajomość tych praw nie tylko przez większość członków społeczeństwa, lecz także przez ludzi wykształconych, a nawet polityków - częstokroć negujących zarówno same prawa, jak i konieczność ich przestrzegania. Brak odpowiednio licznej kadry sędziowskiej, nienależyte wyposażenie techniczne sądów powodują w wielu państwach przewlekłość postępowania, godząc jednoznacznie w prawa człowieka ${ }^{65}$.

Stwierdzenie w aktach normatywnych najwyższej wagi, że dane państwo jest, ,państwem prawa”, „demokratycznym państwem prawnym”, ,socjalnym państwem prawa”, podkreślenie, że jest to państwo szanujące prawa człowieka, wyliczenie takich praw i ich zdefiniowanie ma w gruncie rzeczy jedynie charakter deklaracji i jest wyrazem mniej lub bardziej prawdziwych intencji. Dopiero praktyka życia społecznego decyduje o tym, jak jest w rzeczywistości, czy - i na ile wspomniane deklaracje pozostają bez pokrycia lub wcielane są w życie. Praktyka polityczna i społeczna, decyzje administracyjne i orzeczenia sądowe nie mogą jednak lekceważyć międzynarodowych zobowiązań, jakie przyjęły na siebie poszczególne państwa. Nawet najbardziej szczytne hasła i idee nie mogą usprawiedliwiać w imię racji stanu, potrze-

między różnymi kultami, religiami i wyznaniami. Prawo do Wolności religii zakłada, iż wierni mogą się swobodnie stowarzyszać bez arbitralnych decyzji państwa. Zob., Hasan i Chaush przeciwko Bułgarii - orzeczenie z 26 października 2000 r., Wielka Izba, raport Europejskiej Komisji Praw Człowieka z 26 października 19999., skarga nr 30985/96, w: Nowy Europejski Trybunat..., oprac. M. A. Nowicki, s. 936-941; Kościół Metropolitalny Besarabii i inni przeciwko Mołdawii - orzeczenie z 13 grudnia 2001 r., Izba (Sekcja I), skarga nr 45701/99, ibidem, s. $942,946$.

${ }^{62}$ J. Bojarski, Przeciwdziałanie praniu brudnych pieniędzy, w: Społeczeństwo inwigilowane..., s. 131-142; P. M. Raphael, Pranie pieniędzy - doświadczenia europejskie, w: Przestępczość gospodarcza. Doświadczenia europejskie i amerykańskie, red. A. Siemiaszko, Warszawa 1995, s. 43-44.

${ }^{63} \mathrm{~K}$. Dobrzeniecki, Internet a zjawisko prywatnej cenzury i inwigilacji, w: Społeczeństwo inwigilowane..., s. 181-186; P. Chrzczonowicz, Karnoprawna ochrona wolności sumienia i wyznania w prawie polskim. Problematyka sekt, w: Spoleczeństwo inwigilowane..., s. 115-164.

${ }^{64}$ A. Zieliński, Wplyw Międzynarodowych Paktów Praw Człowieka na przemiany prawno-ustrojowe w Polsce, w: Międzynarodowe Pakty Praw Człowieka, standard prawa i jego realizacja a przyszłe wyzwania. Konferencja naukowa 23-24 marca 2001, Poznań, oprac. R. Wieruszewski, R. Hliwa, Poznań 2002, s. 15-16; Z. Kędzia, Program praw czlowieka ONZ w procesie zmian, ibidem, s. 23-37; H. Suchocka, Aktualne zagrożenia dla realizacji praw człowieka w Polsce, ibidem, s. 45-52.

${ }^{65}$ H. Mądrzak, Prawo do sqdu jako gwarancja ochrony praw człowieka, w: Podstawowe prawa jednostki i ich sqdowa ochrona, red. L. Wiśniewski, Warszawa 1997, s. 186-200; P. Hofmański, Prawo do sqqu w sprawach karnych jako gwarancja ochrony praw człowieka, ibidem, s. 201-220. 
by moralnej obojętności wobec praw człowieka. Prawa te nie są ani pustymi, ani wyświechtanymi hasłami, lecz mają konkretną i ustaloną treść. Nie są ani religią ani ideologią, lecz ideą zaakceptowaną przez demokratyczne państwa i społeczeństwa. Państwo, które łamie prawa człowieka nie jest państwem prawa, a tym bardziej - demokratycznym państwem prawnym. Politycy lekceważący takowe prawa, podżegający do ich łamania stawiają siebie poza obrębem społeczności międzynarodowej i wyrządzają krzywdę współobywatelom. Praw człowieka nie można fetyszyzować, a treść ich nie ma charakteru religijnego, lecz prawny. Przestrzeganie tych praw leży w interesie wszystkich społeczności europejskich.

Warto zauważyć, iż Konstytucja RP przyznaje wolnościom prawom i obowiązkom człowieka i obywatela eksponowane miejsce w hierarchii norm konstytucyjnych. Formułuje ich katalog w podziale na wolności i prawa osobiste (art. 38-56), wolności i prawa polityczne (art. 57-63), wolności i prawa ekonomiczne, socjalne i kulturalne (art. 64-76), wskazując środki ochrony wolności i praw (art. 77-81), wreszcie wskazując obowiązki (art. 82-86). Każda $\mathrm{z}$ tych dziedzin, nie tylko mogła by być, ale już wielokrotnie stawała się przedmiotem szczegółowych analiz, studiów i monografii. W tym miejscy wypada poświęcić jedynie uwagę zakresowi ochrony prawnej wolności człowieka i warunkom ich dopuszczalnych ograniczeń w praktyce. Warto przypomnieć, że art. 31 Konstytucji zawiera dwa zespoły norm, z których pierwszy - wyrażony w ust. 1 i 2 tegoż artykułu formułuje ogólną zasadę wolności, drugi - określony w ust. 3 formułuje przesłanki ustanawiania ograniczeń konstytucyjnych praw i wolności ${ }^{66}$. Wypada zauważyć, że art. $31 \mathrm{w}$ ust. 3 formułuje warunki dopuszczalnych ograniczeń wolności i praw. Zakres tego unormowania ma charakter uniwersalny, gdyż dotyczy wszystkich konstytucyjnych wolności i praw. Jest przy tym wyjątkowy, gdyż zawęża zakres zastosowania wolności i praw konstytucyjnie gwarantowanych. Z treści art. 31 ust. 3 wynika, że ograniczenia w zakresie korzystania z konstytucyjnych wolności i praw mogą być ustanowione wyłącznie w ustawie - i tylko wtedy, gdy są konieczne w demokratycznym państwie dla jego bezpieczeństwa lub porządku publicznego bądź dla ochrony środowiska, zdrowia i moralności publicznej, wreszcie - dla ochrony wolności i praw innych osób. O tej ostatniej płaszczyźnie zwykło się zapominać. W literaturze uznaje się, iż ustanowione ograniczenia korzystania z wolności i praw wynikają z koncepcji interesu publicznego, jako ogólnego wyznacznika granic wolności i praw jednostki ${ }^{67}$.

Bezpieczeństwo państwa, jako podstawa ograniczeń korzystania z praw i wolności, wskazane zostało w treści art. 31 ust. 3 Konstytucji na pierwszym miejscu, aczkolwiek wydaje się, iż nie ma to większego znaczenia. Pojęcie „,bezpieczeństwo państwa” nie zostało precyzyjnie określone. Generalnie przyjmuje się, że jest to stan charakteryzujący się brakiem zagrożeń dla istnienia państwa oraz jego demokratycznego rozwoju, umożliwiający zarówno państwu, jak i narodowi bezpieczną egzystencję i rozwój ${ }^{68}$. Pod pojęciem ,porządku publicznego” - o którym mowa w art. 31 ust. 3 Konstytucji - rozumie się zwykle system urzadzeń prawno-publicznych i stosunków społecznych powstajacych i kształtujacych się w miejscach publicznych, niepublicznych, którego celem i zadaniem jest zwłaszcza ochrona życia, zdrowia,

${ }^{66}$ K. Wojtyczek, Granice ingerencji ustawodawczej, s. 78 i n.

${ }^{67}$ M. Wyrzykowski, Pojęcie interesu publicznego w prawie administracyjnym, Warszawa 1986, s. 28 i n. Warto podkreślić, że ustawodawca nie posłużył się terminem ,interes publiczny”- mimo, że operuje nim w treści Konstytucji (art. 22). Zwraca się przy tym uwagę, że ,interesu publicznego” nie można utożsamiać z ,interesem państwowym”, gdyż w demokratycznym państwie prawnym interes publiczny musi wiązać się z poszanowaniem wolności indywidualnej.

${ }^{68}$ W. Wołpiuk, Sity zbrojne w regulacjach Konstytucji RP, Warszawa 1998, s. 47. 
mienia obywateli i mienia społecznego $i$ zapewnienie normalnej działalności instytucji, zakładów, przedsiębiorstw państwowych, społecznych i prywatnych oraz eliminowanie (usuwanie) różnego rodzaju uciażliwości niebezpiecznych lub niedogodnych dla społeczeństwa i jednostek ${ }^{69}$. Według Kubali, porządek publiczny to istniejący w państwie stan stosunków i urządzeń publicznych oraz odpowiadających im instytucji prawnych zapewniających bezpieczeństwo, spokój oraz ład w zakresie współżycia zbiorowości ${ }^{70}$. Przez „,porządek publiczny” rozumie się najczęściej stan harmonijnego współżycia członków społeczeństwa, obejmując tym terminem zarówno ochronę interesów jednostek, jak i interesu społecznego, który umożliwia normalne funkcjonowanie państwa i społeczeństwa. Uważa się, że jest to minimum sprawności funkcjonowania instytucji państwowych ${ }^{71}$. Niekiedy wskazuje się, że „,porządek publiczny" to dyrektywa takiej organizacji życia publicznego, która zapewniać ma minimalny poziom uwzględniania interesu publicznego oraz oparcie organizacji społeczeństwa na wartościach przez to społeczeństwo podzielanych ${ }^{72}$.

Fakt, że w aktach normatywnych systemu prawnego Unii Europejskiej wielokrotnie zwraca się uwagę na konieczność opracowania kodeksów etyki dziennikarskiej ${ }^{73}$, zmusza z jednej strony do zastanowienia się nad charakterem tych kodeksów, rola jaką one spełniają i treściami przez nie prezentowanymi, z drugiej zaś do refleksji nad samą etyką dziennikarską i rozważeniem, czy jest ona tożsama $\mathrm{z}$ etyką mediów. W literaturze podkreśla się, że etyka dziennikarska jest jedną z etyk profesjonalnych, będąc jednocześnie tzw. etyką stosowaną, czyli jak to ujmowano wcześniej, jedną z etyk szczegółowych ${ }^{74}$. Nie stawia się jednak znaku

${ }^{69}$ Zob. S. Bolesta, Pojęcie porzqdku publicznego w prawie administracyjnym, „Studia Prawnicze” 1983, nr 1, s. 236 .

${ }^{70}$ Zob. W. Kubala, Ochrona porzadku publicznego w polskim prawie karnym, Warszawa 1983, s. 76.

${ }^{71}$ Zob. K. Wojtyczek, Granice ingerencji, s. 188-190.

${ }^{72}$ M. Wyrzykowski, Granice praw i wolności-granice władzy, w: Obywatel, jego wolności i prawa. Zbiór studiów przygotowanych z okazji 10-lecia urzędu Rzecznika Praw Obywatelskich, Warszawa 1998, s. 50.

${ }^{73}$ Uchwalona 1 lipca 1993 r. Rezolucja 1003 Zgromadzenia Parlamentarnego Rady Europy, przyjęta w oparciu o sprawozdanie Komisji Kultury i Edukacji (stanowi najpoważniejszą, chociaż nie jedyną próbę określenia zasad etyki dziennikarskiej w systemie Rady Europy, zob. Doc. 6854, report of the Committee on Culture and Education, Reporter: Mr Núňez Encabo. Assembly debate on 1 July 1993 (42-nd Sitting). Text adopted by the Assembly on 1 July 1993 (42-nd Sitting). W rezolucji wyrażono pogląd, iż środki masowej informacji muszą zobowiązać się do wypracowania norm etycznych gwarantujących wolność wypowiedzi i fundamentalne prawa obywateli do otrzymywania prawdziwych informacji i uczciwych opinii. Zauważono, że niezależnie od praw i obowiązków, określonych w odpowiednich normach prawnych, media ponoszą etyczną odpowiedzialność w stosunku do obywateli i społeczeństwa, szczególnie w procesie formowania postaw obywatelskich, M. Kiernan, Media Ethics, London-New York 1998, s. 79 in.; J. Darmo, Etyka w środkach masowego przekazu. Obraz świata w mediach, ,Zeszyty Prasoznawcze” 1995, nr 1-2, s. 52; T. Kononiuk, B. Michalski, Problemy prawne zawodu dziennikarskiego, Warszawa 1998, s. 89 i n.; Rezolucja 1003 Zgromadzenia Parlamentarnego Rady Europy z 1 lipca 1993 r. w sprawie etyki dziennikarskiej, „Zeszyty Prasoznawcze" 1994, R XXXVI, nr 3-4 (14), s. 155-160; Resolution 1003 (1993) on the Ethnics of Journalism, w: Recommendations and Resolutions Recommendations and Resolutions Adopted by the Parliamentary Assembly if the Council of Europe, Strasbourg 2000, Directorate General on Human Rights, s. 118-124.

${ }^{74} \mathrm{~W}$ tej sytuacji etyka dziennikarska byłaby jedną z odmian etyki zawodowej. Etykę zawodową określa się w literaturze jako zespót norm i zasad okréslajacych, jak powinny zachować się osoby tworzace dana grupę zawodowa zob. S. Zakrzewski, Etyka dziennikarska w: Dziennikarstwo od kuchni, red. A. Niczyperowicz, Poznań 2001, s. 210; także L. Lakomy, Etyczne granice współczesnego dziennikarstwa w: Media a Polityka, red. M. Szpunar, Rzeszów 2007, s. 227. Jak podkreśla Tadeusz Kononiuk, etyka zawodowa, należąca do najstarszych etyk, ma swoje uzasadnienie w tradycji i powinna regulować zachowania związane z takimi wartościami, jak prawda, wolność i godność. Zob. T. Kononiuk, Etyczne dziennikarstwo, w: Poradnik dla wydawców i dziennikarzy prasy lokalnej, red. A. Herman, Wrocław 1998, s. 116-117. Por. także M. D. Baylet, Professional Ethics, Belmond 1989; D. E. Wueste, Professional Ethics and Social Responsibility, Lauham 1994; T. Labieniec, Etyka-etyka zawodowa-prawo. Zarys problematyki, „Prokurator” 2002, nr 2. 
równości między etyką dziennikarską a etyką mediów. Tę ostatnią widzi się zwykle jako całokształt teoretycznej refleksji nad mediosferq, jako przestrzeniq moralności, a więc obszar ludzkich wyborów i działań medialnych, która stara się wypracować kryteria ocen etycznych obecnych w nich treści i firm medialnych. Podkreśla się przy tym, że etyką mediów jest etyka twórców medialnych i dziennikarzy, że w tym obszarze rozwija się ona jako etyka dziennikar$s k a^{75}$. Tak więc w tym ujęciu etyka dziennikarska jest częścią etyki mediów, a w ramach tej ostatniej mieści się też etyka publiczności (etyka odbiorców) ${ }^{76}$. Objęcie zakresem etyki mediów także zachowań etycznych odbiorców jest dość charakterystyczną próbą „podzielenia się" z tą ostatnią grupą odpowiedzialnością za standardy moralne przekazów dziennikarskich. Widać tu wyraźnie dążenie do konstatacji, iż przekazy dziennikarskie łamią etyczne standardy tylko dlatego, że domagają się tego odbiorcy. Teza ta wielokrotnie prezentowana była przez przedstawicieli tabloidów, szukających w ten sposób usprawiedliwienia przed zarzutami pogoni za sensacją i epatowania publiczności drastycznymi opisami.

W literaturze wielokrotnie przy różnych okazjach podkreśla się, że zawód dziennikarza wymaga profesjonalności, zauważając jednak, że winien on być wykonywany przy zachowaniu norm etyki zawodowej ${ }^{77}$. Zauważa się, że dobre moralne sprawowanie ról zawodowych wyrażane jest moralnie dobrym samoosądem, jako nieodłączną cechą dobrego charakteru i dobrej pracy dziennikarza. Wewnętrznie dobra moralnie osoba jest jednostką o rozwiniętej wrażliwości moralnej nie ulegająca destrukcyjnym wpływom niemoralnego otoczenia. Jeżeli jej moralna wrażliwość ulegnie erozji, powodując - bez krytycznej reakcji - przekraczanie moralnych granic, to nowe, niemoralne granice wraz z upływem czasu stają się akceptowanym standardem ${ }^{78}$.

Reakcją na łamanie standardów etyki dziennikarskiej, podobnie jak wszelkiej etyki zawodowej jest wytyczanie granic moralnych zachowań w treści kodeksów etycznych. W literaturze podkreśla się, że tworzenie kodeksów etyki zawodowej to z jednej strony symptom środowiskowej megalomanii, z drugiej - przejaw wygórowanych aspiracji zawodowych i ukrytych kompleksów wobec tych grup, które z racji pełnionych ról społecznych cieszą się szczególnym prestiżem i od dawna posiadają zbiory norm etycznych regulujących ich działalność, jak np. lekarze, adwokaci, notariusze, architekci. Tak więc tworzenie kodeksu etyki zawodowej jest $\mathrm{z}$ jednej strony przejawem potrzeby awansu społecznego określonego zawodu, $\mathrm{z}$ drugiej jednak zdaje się wynikać z pewnej mody, której ulegają najróżniejsze środowiska zawodowe ${ }^{79}$.

Kodeksy etyki z natury rzeczy wskazująjak powinni postępować przedstawiciele jakiegoś zawodu, wypełniając swoje funkcje. Treść ich jest z jednej strony skierowana do określonej grupy zawodowej, z drugiej zaś - do kontrahentów tej grupy - odbiorców wytwarzanych przez nią dóbr lub świadczonych przez nią usług ${ }^{80}$. Tak więc w treści kodeksu etyki przedsta-

\footnotetext{
${ }^{75}$ M. Dożdż, Etyczne orientacje w mediosferze, Tarnów 2006, s. 36-37; zob. także J. Pleszczyński, Etyka dziennikarska, Warszawa 2007, s. 21.

${ }^{76}$ Zob. M. Kunczik, A. Zipfel, Wprowadzenie do nauki o dziennikarstwie i komunikowaniu, Warszawa 2000, s. 101 .

${ }^{77}$ Media i dziennikarstwo w Polsce 1989-1995, red. G. G. Kopper, J. Rutkiewicz, K. Schliep, Kraków 1996, s. 9; P. Legutko, D. Rodziewicz, Mity czwartej władzy, Karków 2002, s. 159.

${ }^{78}$ A. T. Kronman, The Lost Lawier. Failing Ideals of the Legal Profession, Cambrige, Mass-London, England 1994, s. 11 i n.

${ }^{79}$ N. G. E. Harris, Codes of kondukt for journalist, w: Ethical issues in Journalism and the Media, red. A. Belsey, R. Chadwick, Routledege, London-New York 2006, s. 62.

${ }^{80}$ I. Lazari-Pawłowska, Etyki zawodowe jako role społeczne w: Etyka. Pisma wybrane, Wrocław 1992, s. 84.
} 
wiciele określonego zawodu bądź korporacji winni orientować się jak mają postępować, a osoby spoza tego zawodu, wchodzące w interakcje z jego przedstawicielami, mogą się dowiedzieć jakie standardy obowiązują ich kontrahentów. Liczba kodeksów etyki dziennikarskiej - noszących różne nazwy występujących także jako: „karty mediów”, „karty dziennikarstwa”, „karty etyczne”, „deklaracje praw i obowiązków” itd. stale rośnie zarówno w Polsce, jak i na świecie. Wszechobecność kodeksów etyki nie świadczy jednak wcale o ich potrzebie i pożytkach, jakie niosą. Niewątpliwie jednak kodeksy etyki zwiększają wiarygodność określonego zawodu, przyczyniając się pośrednio do sukcesu finansowego jego przedstawicieli. Dotyczy to także zawodu dziennikarskiego ${ }^{81}$. Nie sposób jednak zaprzeczyć, że wielu dziennikarzy i znaczące grono medioznawców kwestionuje wszelkie korzyści płynące z istnienia i tworzenia kodeksów etyki dziennikarskiej, uznając je za zbędne samoograniczenia i niepotrzebne zobowiązania. Podnoszą oni, że dziennikarze to ludzie o szczególnej wrażliwości, wyostrzonym zmyśle moralnym i poczuciu przyzwoitości, którym to cechom dają dojść do głosu wykonując swój trudny i odpowiedzialny zwód ${ }^{82}$. Krytykując potrzebę tworzenia kodeksów etyki dziennikarskiej, zwraca się także często uwagę na fakt, że mają one zwykle charakter ogólnikowy, są mało konkretne, także trudno w ich treści znaleźć wskazówki potrzebne dla rozwiązywania nie tylko bardziej złożonych sytuacji, ale nawet codziennych wattpliwości. Niekiedy podnosi się, że istnienie kodeksów to usankcjonowana forma autocenzury, ograniczająca suwerenność dziennikarza, a w konsekwencji - wolność słowa. Zauważa się także, iż kodeksy stępiają wrażliwość etyczną, poczucie indywidualnej odpowiedzialności, tworząc niebezpieczne mechanizmy kontroli, sprzyjając konformizacji społeczeństwa ${ }^{83}$.

W powstawaniu kodeksów etyki dziennikarskiej dostrzega się także przejaw braku poczucia bezpieczeństwa i formę obrony przed narastającymi falami niechęci i nieufności odbiorców. W literaturze poddaje się w wątpliwość możliwość przyczyniania się kodeksów etyki do podniesienia poziomu moralności dziennikarskiej w praktyce. Widzi się w nich wygodny dla mediów mechanizm, którego istnienie ma przekonać opinię publiczną, że środki przekazu i pracujący w nich dziennikarze nie potrzebują żadnej kontroli, gdyż legitymują się wysokimi standardami moralnymi i wypracowanymi metodami samokontroli ${ }^{84}$. Zdaniem niektórych badaczy, kodeksy etyki dziennikarskiej służą w większym stopniu budowaniu obrazu pracy na zewnątrz, niż wewnętrznemu regulowaniu zachowań dziennikarskich. Wskazuje się, że powstawanie kodeksów dziennikarskich jest konsekwencją tego, że moralność deklarowana nie przekłada się wprost na praktykę moralną. Deklaracje moralne mają to do siebie, że można je bez większego ryzyka upublicznić głosząc nierealistyczne hasła i obiecując wypełnienie zobowiązań, którym w praktyce nie sposób zadośćuczynić. Tworzący kodeksy w mniejszym lub większym stopniu zdają sobie przy tym sprawę, że wprowadzenie w życie treści zawartych w nich norm jest niezmierne trudne, a odpowiedzialność za obietnice i deklaracje niemożliwa do wyegzekwowania wobec braku jakichkolwiek sankcji administracyjnych bądź organizacyjnych. W literaturze sami dziennikarze i większość medioznawców rozpływa się

\footnotetext{
${ }^{81}$ Deontologia mediów, Warszawa 2007, s. 71; T. Sasińska-Klass, Etyka zawodów medialnych czyli jak zachowywać się przyzwoicie w świecie mediów, w: Komunikatorzy. Wplyw, wrażenie, wizerunek, red. A. Drzyciński, Warszawa-Bydgoszcz 2000, s. 333 i n.

${ }^{82}$ M. Kunczik, A. Zipfel, Wprowadzenie..., s. 100-103. Zob. także C. G. Christians, T. L. Covert, Teaching Ethics in Jourlanism Education, 1980, s. 30-31.

${ }^{83}$ Ch. Frost, Media Ethics and Self-Regulation, Longman, Harlow 2000, s. 95.

${ }^{84}$ T. Laitila, Journalistic codes of ethics in Europe, w: Communication Theory \& Research. An EJC Anthology, red. D. McQuail, P. Holding, E. D. Bens, Sage, London 2005, s. 194; D. Pritchard, M. Peroni Morgan, Impact of ethic codes in judgements by journalists: A natural experiment, ,Journalism Quarterly” 1989, nr 66, s. 47.
} 
nad szczytnymi hasłami kodeksów etyki, wskazując, że ustalają one wysokie standardy moralne, ochraniają informatorów dziennikarzy, dostarczają poczucia bezpieczeństwa pracownikom środków przekazu, chronią dobra osobiste, eliminują nadużycia i oszustwa ${ }^{85}$. W treści kodeksów etyki odnaleźć można te same fundamentalne zasady, identyczne zakazy i odwołanie się do podobnych podstawowych wartości. Wskazuje się w nich zwykle, że dziennikarz ma być kompetentny, niezależny, lojalny, uczciwy, prawdomówny, dokładny, szanujący dobra osobiste innych osób, w szczególności godność. Podkreśla się, że ma nie kłamać, nie dopuszczać się plagiatów, służyć prawom człowieka, szanować demokrację, inicjować publiczną debatę, dbać o kulturę słowa ${ }^{86}$. W doktrynie zauważa się, że w europejskich kodeksach szczególnie akcentuje się prawdomówność, uczciwość, szacunek dla prywatności, odpowiedzialność wobec opinii publicznej, niezależność, nieprzekupność, lojalność, bezinteresowność, potrzebę oddzielania faktów od opinii, konieczność ochrony zawodowej integralności środowiska, potrzebę ochrony wolności słowa i przekonań, niezbędność poszanowania prawa autorskiego ${ }^{87}$. Tak więc kodeksy nie wychodzą poza wskazania dekalogu, przy czym generowane przez nie treści mają charakter publicystycznych oczywistości bądź etycznego banału $^{88}$. Podkreśla się, że kodeksy etyki dziennikarskiej bardziej służą tworzeniu obrazu prasy na zewnątrz, niż regulacji zachowań dziennikarskich. Ukrytym celem ich istnienia jest autopromocja środowiska, konkretnego tytułu, redakcji, grupy zawodowej itd. Zawód dziennikarza ukazywany jest jako zaszczytna służba, a sam żurnalista - jako osoba spełniająca ważną misję, działająca z powołania, która bezinteresownie służy społeczeństwu, dobru publicznemu, a przede wszystkim - prawdzie, prawu i sprawiedliwości. W praktyce wielokrotnie można się przekonać, że jest inaczej. Zauważa się, że dzięki kodeksom środowisko dziennikarskie z łatwością może zasłonić się przed publiczną krytyką, powołując się na slogany zawarte w ich treści. Warto przy tym zauważyć, że rozwiązania kodeksów etyki dziennikarskiej pomijają prawa i obowiązki właścicieli tytułów prasowych, stacji radiowych i telewizyjnych, a to właśnie oni poprzez swoje decyzje mogą dopuszczać się i w praktyce dopuszczają się naruszeń nie tylko zasad etycznych, ale i częstokroć norm prawnych. Dziennikarze nader często są w praktyce tylko narzędziami w ich ręku.

W praktyce mogą się także pojawić spory co do zakresu pojęcia „moralności publicznej”, którym operuje Konstytucja w treści art. 31 ust. 3. Termin „moralność” ma wiele znaczeń. $\mathrm{Z}$ jednej strony oznacza zespół norm moralnych uznawanych przez daną osobę lub grupę osób, z drugiej strony praktykę postępowania według określonych norm moralnych. Systematyczny sposób wyłożenia pewnego zespołu norm moralnych określany jest jako etyka normatywna (doktryna moralna). Zespół twierdzeń o moralności, tj. o treści przyjmowanych norm moralnych, ich powiązań, kształtowaniu i oddziaływaniu, nosi miano etyki opisowej (nauki o moralności). Normy moralne mają przeważnie ogólnikowy, dyrektywny charakter. Nie są one nazbyt dokładnie sprecyzowane ani skodyfikowane. Normy prawne, oprócz nielicznych norm ogólnych, są bardziej szczegółowe od moralnych i bardziej precyzyjne. Sfery stosowania norm prawnych i norm moralnych w znacznej części się pokrywają. Istnieją jednak pewne dziedziny, które są regulowane tylko bardzo ogólnie przez prawo, natomiast bar-

\footnotetext{
${ }^{85}$ A. D. Gordon, J. M. Kittross, J. T. Merrill, C. Reuss, Contoversiest in Media Ethics, Longman, New York 1999 , s. 58.

${ }^{86}$ T.-J. Bertrand, Media Ethics \& Attountability Systems, Transaction Publishers, New Brunswick-London 2000, S. $44-45$.

${ }^{87}$ T. Laitila, Journalistic..., s. 198 i n.

${ }^{88}$ J. Jastrzębski, Na rynku wartości. O mediach i etyce dziennikarskiej, Wrocław 2009, s. 107-108.
} 
dzo szczegółowo przez normy moralne. Są czyny, na które państwo nie reaguje prawnie, a które wywołują jednak reakcję moralną. Normy prawne nie regulują wewnętrznej postawy człowieka. Czynią to natomiast normy moralne. Cechą prawa i moralności jest to, że stanowią zespół norm postępowania regulujących nader często to samo zachowanie. Istnieją jednak normy prawne, które nie są jednocześnie moralnymi i normy moralne, które nie mają odpowiednika wśród norm prawnych. Prawo, podobnie jak moralność, samodzielnie reguluje swoimi normami określony obszar stosunków. Prawo i moralność stanowią dwa odrębne systemy norm, posiadając równą moc obowiązującą, chociaż płynącą z różnych źródeł. Normy prawne i normy moralne mogą mieć podobną treść. Innymi słowy - to, co zakazane prawem, normą prawną jest jednocześnie zakazane przez moralność. Może być jednak i tak, że to, co zakazane przez normę prawną jest jednocześnie nakazane przez moralność i na odwrót. W końcu może zajść i taka sytuacja, że nakazy i zakazy moralne są, z punktu widzenia prawa, obojętne. Konstatacja ta prowadzi do wniosku, że może czasem zachodzić konflikt między normami prawnymi a moralnymi. Norm moralnych nie należy mylić z normami obyczajowymi. Normą obyczajową jest taka reguła postępowania, która ukształtowała się w świadomości ludzi w wyniku społecznego nawyku, wielokrotnego powtarzania w określonych sytuacjach. Normy te, w odróżnieniu od moralnych, nie służą wartościowaniu zachowań ludzi z punktu widzenia dobra i zła.

W literaturze istnieją zasadnicze dwa nurty pojmowania moralności: perfekcjonistyczny, według którego przedmiotem oceny moralnej jakiegoś postępowania jest to, w jakim stopniu odpowiada ono pewnym wzorcom doskonałości człowieka, zresztą historycznie zmiennym, oraz nurt solidarnościowy, gdzie przedmiotem oceny jest to, w jakim stopniu przyczynia się ono do sprawiedliwego dobra innych ludzi. Normy moralne, według koncepcji perfekcjonistycznej, mają wskazywać, jak człowiek ma żyć, aby być doskonałym, jak żyć godnie, natomiast według koncepcji solidarnościowej mają one wskazywać, jak żyć tak, aby nie tylko nam z innymi, ale i innym z nami było dobrze. Trudno dociec, na gruncie jakiej koncepcji stoi ustawodawca w art. 31 ust. 3 Konstytucji. Wydaje się, iż sprzeczne z moralnością w świetle tego przepisu będą czyny niezgodne z pojmowaniem moralności tak przez jeden, jak i drugi nurt. W Konstytucji o „moralności publicznej” mowa w art. 31 ust. 3. Natomiast w art. 45 ust. 2 i w art. 53 ust. 5 mowa o ,moralności”. Wykładnia językowa prowadziłaby do wniosku, iż pojęcie „,moralność”, o jakim mowa w art. 45 ust. 2 i art. 53 ust. 5, ma zakres szerszy od moralności publicznej, o której traktuje art. 31 ust. 3 Konstytucji. Wykładnia taka wydaje się jednak pomijać warstwę teleologiczną. Trudno bowiem dopatrzyć się przesłanek, które nakazałyby rozróżniać pojęcia moralności we wszystkich trzech artykułach Konstytucji. Zauważyć należy, że w art. 10 ust. 2 Europejskiej Konwencji Praw Człowieka mowa tylko o „moralności”, natomiast w art. 9 ust. 2 tejże konwencji pojawia się „moralność publiczna”. Powołane już Zasady z Syrakuz odwołują się do „moralności publicznej”. Fakt ten musi pogłębiać wątpliwości co do zakresu pojęć „moralność”, „moralność publiczna”. Pojęcie „moralności publicznej”, którym posłużył się ustawodawca w Konstytucji, wydaje się odnosić do moralności społeczeństwa polskiego, do tych norm moralnych, które są wspólne dla przeważającej części tego społeczeństwa. Brak podstaw do twierdzenia, że termin „moralność publiczna” należy rozumieć jako zasady moralne odnoszące się do życia publicznego lub regulujące zachowania publiczne dostępne dla nieograniczonego kręgu osób. W praktyce zauważona nieostrość terminologiczna może powodować trudności i wątpliwości, stając się źródłem konfliktów ${ }^{89}$.

\footnotetext{
${ }^{89}$ Zob. L. Lang, Prawo i moralność, Warszawa 1989; M. Ossowska, Normy moralne. Próba systematyzacji, Warszawa 1970, s. 230-236; taż, Podstawy nauki o moralności, s. 37 i n.; Z. Ziembiński, Etyczne problemy prawo-
} 
$\mathrm{Na}$ całym świecie istnieje dość silna tendencja kodyfikowania norm etycznych dotyczących różnych zawodów. Podkreśla się, że dobre moralnie sprawowanie ról zawodowych wyrażane jest moralnie dobrym samoosądem jako nieodłączną cechą dobrego charakteru i dobrej pracy będących z kolei przedmiotem osądów społecznych. Ten dobry samoosąd uważany jest za charakterystyczną wartość, cnotę wewnętrznego życia moralnego, pozwalającą pracownikowi na pozostawanie w zgodzie z samym sobą. Moralnie dobra osoba to jak podnosi się w literaturze osoba o rozwiniętej wrażliwości moralnej, nie ulegająca destrukcyjnym wpływom niemoralnego otoczenia. Jeżeli moralna wrażliwość dotknięta zostanie erozją umożliwiając bezkrytycznej reakcji przekraczanie granic moralnych to te nowe niemoralne granice $\mathrm{w}$ miarę upływu czasu staną się akceptowanym standardem ${ }^{90}$. Tworzenie kodeksów etycznych dla poszczególnych zawodów ma przeciwdziałać tego typu tendencjom. Zawód dziennikarski należy w opinii społecznej, a także w oglądzie samych dziennikarzy do tych, które szczególnie dotknięte zostały upadkiem etycznych standardów. Wyjaśniając to stanowisko wskazuje się najczęściej na uwarunkowania ekonomiczne, demoralizację dziennikarzy przez pracodawców i społeczeństwo wreszcie brak wzorców zachowań etycznych. Panaceum na łamanie mniej lub bardziej uświadamianych sobie przez poszczególnych dziennikarzy standardów etycznych jest próba określenia granic moralnych zachowań dziennikarskich w różnorakich kodeksach etycznych dziennikarskich zbiorach zasad. W dużej mierze sami dziennikarze - aczkolwiek na pewno nie wszyscy - zauważają, że etyka dziennikarska nie jest tylko sprawą samych dziennikarzy. Specyfika dziennikarskich funkcji społecznych polega na tym, że moralna jakość ich pracy rzutuje na jakość życia społeczeństwa ${ }^{91}$. Przekonaniu temu mniej lub bardziej intuicyjnie hołduje polski ustawodawca, domagając się od dziennikarza szczególnej staranności, a więc wyższej od tej jaką oczekiwać można od lekarza (art. 12 ust. 1 pkt 1 pr.pr.). Tym wszystkim należy tłumaczyć dążenie do skodyfikowania dziennikarskich norm etycznych, do tworzenia kodeksów etyki dziennikarskiej. Charakterystycznym jest przy tym to, że pojawiają się odrębne kodeksy dotyczące członków poszczególnych stowarzyszeń dziennikarskich: oddzielnie dla dziennikarzy radiowych, telewizyjnych i prasy drukowanej, w końcu osobne dla zajmujących się różnymi działami żurnalistyki (sportem, kulturą, sprawozdawczością parlamentarną, sądową, reklamą itd.). Czasami normy dziennikarskiej etyki zawodowej nie są wpisywane do odrębnych zbiorów, lecz stanowią integralną część statutów: redakcji bądź stowarzyszeń, względnie regulaminów redakcji ${ }^{92}$.

Ograniczenia w zakresie konstytucyjnych wolności i praw mogą wynikać z potrzeby poszanowania wolności i praw innych osób. Sugeruje to równorzędność chronionych wartości, aczkolwiek zarówno w doktrynie, jak i judykaturze istnieje wyraźna tendencja do hierarchizowania wolności i praw ${ }^{93}$.

znawstwa, Warszawa 1972; tenże, Podstawy nauki o moralności, Poznań 1991, s. 5 i n.; tenże, Zarys zagadnień etyki, Poznań-Toruń 1994, s. 13 i n.; J. Grad, Obyczaj a moralność, Poznań 1993, s. 90 i n.

${ }^{90}$ Zob. A. T. Kronam, The Lost Lawyer. Failing Ideals of the Legal Profession, Cambridge, Mass-London, England 1994, s. 11 i n.

${ }^{91}$ Zob. B. Golka, Etyka dziennikarska: utopia czy ratunek?, „Zeszyty Prasoznawcze” 1995, nr 1-2, s. 22-32; T. Płonkowski, Amerykańska koncepcja społecznej odpowiedzialności dziennikarzy, Warszawa 1995, s. 77-87.

92 Zob. B. A. Porfirio, Codigos dentologicos los mediom de comunicacion, Madryt 1984, passim; L. Brajnović, Deontologia periodistica, Madryt 1978, passim; zob. także tenże, Kodeksy deontologii dziennikarskiej, w: Dziennikarski etos. Z wybranych zagadnień deontologii dziennikarskiej, red. Z. Kobylińska, R. D. Grabowski, Olsztyn 1996.

${ }^{93}$ K. Wojtyczek, Granice, s. 198-200. Warto w tym miejscu zauważyć, że wbrew utartemu przekonaniu, wolność słowa i innych środków przekazu, będąca zasadą konstytucyjną oraz wolność wyrażania poglądów, a także pozyskiwania i rozpowszechniania informacji (art. 54 Konstytucji) nie ma charakteru nadrzędnego w stosunku do takich wartości jak godność człowieka i prawo do poszanowania dobrego imienia. 
Konstytucja zapewnia, iż wolność podlega ochronie prawnej, stwierdzając, że nikomu, a więc organom państwa i osobom fizycznym bądź prawnym, nie wolno naruszać wolności człowieka. Ochronie prawnej podlegają jednak tylko takie zachowania jednostki, które nie godzą w wolności i prawa innych. Ustawodawca przewiduje możliwość wprowadzenia ograniczeń w zakresie korzystania z konstytucyjnych wolności i praw, stwierdzając jednak, iż ograniczenia te nie mogą naruszać istoty wolności i praw. Pojęcie ,,istoty wolności i praw” nie zostało jak dotąd zdefiniowane w doktrynie. Wykładnia językowa nakazuje uznać, że ,istotą” jest to, co jest zasadniczą częścią czegoś, to sedno konkretnej sprawy, jądro kwestii ${ }^{94}$. Ustalenie, co jest istotą poszczególnych wolności i praw, będzie musiało nastąpić później w drodze wykładni praktycznej i doktrynalnej. Ograniczenia wolności mogą być ustanowione tylko w ustawie i wyłącznie wówczas, kiedy są konieczne w demokratycznym państwie, a konieczność ta dyktowana jest potrzebą bezpieczeństwa lub porządku publicznego bądź ochroną środowiska, zdrowia i moralności publicznej albo wolności praw innych osób (art. 31 ust. 3 Konstytucji). Przyjęta klauzula ogólna, ograniczająca zakres korzystania z konstytucyjnych wolności, może mieć zastosowanie do wszystkich wolności i praw regulowanych przez Konstytucję, a więc także do wolności wypowiedzi. W doktrynie zwraca się uwagę, że tego typu rozwiązanie nie jest znane standardom międzynarodowym, dotyczącym praw człowieka, które klauzule ograniczające przypisują każdorazowo do poszczególnych praw poddanych działaniu takich ograniczeń, a nie formułują klauzuli ogólnej ${ }^{95}$. Międzynarodowe standardy nie wskazują także potrzeby ochrony środowiska jako jednej z podstaw ograniczenia w zakresie korzystania z konstytucyjnych wolności i praw.

Art. 31 ust. 3 Konstytucji dotyczy tylko tych wolności, które zostały zagwarantowane w konstytucji, w tym także tych, które nie znalazły się w treści rozdziału $\mathrm{II}^{96}$, natomiast nie odnosi się do tych wolności i praw, które funkcjonują samoistnie bez odniesienia konstytucyjnego, a wysłowione zostały przez umowy międzynarodowe ${ }^{97}$. Nie oznacza to jednak, że ustawodawca miałby w stosunku do takich praw i wolności nieograniczoną swobodę ich krępowania.

Próbując obejść granice prawne wyznaczające ramy wolności prasy oraz bariery wzniesione przez kodeksy etyki dziennikarze uciekają się do manipulacji przekazem prasowym. Zakres przedmiotowych rozważań nie pozwala poświęcić szczegółowszej uwagi problematyce etymologii słowa manipulacja. Zresztą kwestie te były już przedmiotem dociekań autorów rozlicznych monografii ${ }^{98}$. Manipulacja jest jednym ze sposobów wpływania na zachowanie jednostki bądź grupy osób. W literaturze uważa się, że istnieją dwa rodzaje wpływu społecz-

${ }^{94}$ Zob. Stownik języka polskiego, red. M. Szymczak, t. 1, Warszawa 1988, s. 809.

95 Zob. Prawo konstytucyjne, red. Z. Witkowski, Toruń 1998, s. 86.

${ }^{96}$ K. Wojtyczek, Granice..., s. 84-85.

${ }^{97}$ P. Winczorek, Komentarz do Konstytucji Rzeczypospolitej Polskiej z dnia 2 kwietnia 1997, Warszawa 2000, s. 50. Stanowisko to zaaprobował w licznych wyrokach Trybunał Konstytucyjny, zob. wyroki z 6 lipca 1999 r. (P 2/99, OTK ZU 1999, nr 5, poz. 103), z 10 lipca 2000 r. (SK 21/99, OTK ZU 2000, nr 5, poz. 144), z 2 lipca 2000 r. (U 7/01, OTK ZU 2002, nr 4/A, s. 702).

${ }^{98}$ Zob. M. Karwat, Sztuka manipulacji politycznej, Toruń 2001, s. 10-39; F. d'Almeida, Manipulacja, Gdańsk 2004, s. 24-35; R. Dyoniziak, Sondaże a manipulowanie społeczeństwem, Kraków 1997, s. 22-30; wydanie nieco zmienione pod tym samym tytułem Toruń 2004; P. Pawełczyk, Socjotechniczne aspekty gry politycznej, Poznań 2000, s. 53 i n.; P. Pawełczyk, D. Piontek, Socjotechnika w komunikowaniu politycznym, Poznań 1999, s. 61-83; J. Puzynina, Język wartości, Warszawa 1992, s. 203; D. Doliński, Psychologia wplywu społecznego, Warszawa 2000, s. 14; por. także K. T. Teplic, Wielki Manipulator, w: M. Machiavelli, Ksiqżę. Rozważania nad pierwszym dziesięcioksięiem historii Rzymu Liwiusza, Warszawa 1878, s. 5. 
nego, a mianowicie informacyjny i normatywny ${ }^{99}$. Manipulując jednostką czy całymi grupami społecznymi dziennikarze, mniej lub bardziej świadomie, uciekają się do rozmaitych metod i stosują swoiste narzędzia ${ }^{100}$. Uciekają się do wykorzystywania i kształtowania stereotypów, mitów, tworzenia i rozpowszechniania plotek, nie gardzą kamuflażem, reklamą, huśtawką emocji ${ }^{101}$. Oczywiście możliwe jest stosowanie wobec tego rodzaju działań rozmaitych technik obronnych, dość szczegółowo opracowanych w literaturze ${ }^{102}$. Manipulacji dotyczą w szczególności programy informacyjne, reportaże i publicystyka, które dostarczają widzowi obrazowych konkretów i uogólnionych ocen sytuacji ${ }^{103}$. Manipulacja informacją ma miejsce mimo ugruntowanego w literaturze mitu obiektywizmu ${ }^{104}$, ugruntowuje ją także niezbędna selekcja informacji ${ }^{105}$. Manipulowanie informacją może być wynikiem przyjętych założeń politycznych, przejawiać się w poziomie hierarchii wiadomości, w narzucaniu ocen podanych informacji, w przemilczaniu pewnych wiadomości, w powoływaniu się na racje większości, kreowaniu faktów medialnych, w powoływaniu się na autorytety, budowaniu skojarzeń pozytywnych lub negatywnych ${ }^{106}$. W wyniku wspomnianych działań dziennikarzy, redakcji i wydawcy dochodzi do kreacji rzeczywistości, która swym obrazem różni się w znaczący sposób od prawdziwych wydarzeń, ale przekazywana jest odbiorcy jako wysoce obiektywna. Tego rodzaju działania są praktycznie bezkarne, gdyż ani prawo prasowe, ani żadna $\mathrm{z}$ innych ustaw nie zawiera w swej treści przepisów chroniących przed manipulacja. W nikłym stopniu ochronę stanowić mogą przepisy Kodeksu karnego odnoszące się do zniesławienia (art. 212), i z rozdziału 7 ustawy prawo prasowe art. 44, w myśl którego niedopuszczalne jest utrudnianie bądź tłumienie krytyki prasowej oraz art. 46, który stanowi odpowiedzialność karną za uchylanie się od opublikowania sprostowania lub odpowiedzi, bądź publikowanie takich sprostowań wbrew warunkom określonym w ustawie ${ }^{107}$. Możliwe jest

${ }^{99}$ E. Aronson, Człowiek - istota społeczna, Warszawa 1987, s. 27; por. także rozważania R. Cjaldiniego dotyczące praktycznych technik wywierania wpływu na ludzi, zob. R. Cjaldini, Wywieranie wpływu na ludzi, Gdańsk 2001, s. 27.

${ }^{100}$ Zob. J. Warchala, Horyzonty manipulacji: perswazja, manipulacja, interpretacja, w: Manipulacja w języku, Lublin 2004, s. 52.

${ }^{101}$ A. Kadragić, P. Czarnowski, Publik relations, czyli promocja reputacji. Praktyka działania, „Bisness Press”, Warszawa 1996, s. 20; R. Detweiler, What Every Succesful Executive Should Know About His Press Officers Terrible Secrets, „Poubli Relation Journal” 1976, nr 32, s. 20-23; E. Goffman, Frame Analysis: An Essay on the Organization of Experience, Northeastern University Press, Harmondsworth 1974.

${ }_{102}$ Zob. J. Dumin-Borkowski, Zrozumienie-tarcza przed manipulacja, w: B. Siemieniecki, Manipulacja, media, edukacja, Toruń 2007, s. 263; P. Fortuna, Obrona przed wplywem telewizji, Lublin 2007, s. 61-106; J. Jońca-Jasiński, Bieguny manipulacji, „Charaktery” 2001, nr 2, s. 30; E. Bajcar, Szczepionka na uległość, „Charaktery” 2002, nr 10, s. 12 i n.; J. Bralczyk, O języku propagandy politycznej lat 70, Warszawa 2001, s. 76; M. Mrozowski, Media masowe. Władza, rozrywka, biznes, Warszawa 2001, s. 216.

${ }^{103}$ T. Bogucka, Pomóż, miłościwy Panie, „Gazeta Wyborcza” 2000, 27-28 maja, s. 20.

${ }^{104}$ P. Legutko, D. Rodziewicz, Mity czwartej władzy, Kraków 2002, s. 13.

105 W. Jabłoński, Kreowanie informacji, Warszawa 2006, s. 88 i n.

${ }^{106}$ K. Prajzner, Sensacja i nuda. Analiza dwóch serwisów informacyjnych na przykladzie Faktów i Panoramy, w: Lustra i krzywe zwierciadła. Społeczne konteksty kina i telewizji, red. K. Kleisy, G. Skonieczko, Kraków 2000, s. 189; M. Mrozowski, Media masowe..., s. 384; M. Niezgoda, Rzeczywistość spoleczna czy rzeczywistość telewizyjna, w: Radio i telewizja. Informacja, kultura, polityka, red. W. Dudek, Katowice 2000, s. 97; C. Michalski, Ministerstwo prawdy, Kraków 2000, s. 112.

107 Trybunał Konstytucyjny w wyroku z dnia 22 lutego 2005 r. (K 10/04, OTK-A 2005, nr 2, poz. 17) stwierdził, że art. 46 ust. 2 pr.pr. w części obejmującej zwrot: Jeżeli pokrzywdzonym jest osoba fizyczna, jest niezgodny z art. 32 Konstytucji RP oraz nie jest niezgodny z art. 54 ust. 1 w zw. z art. 31 ust. 3 Konstytucji RP. W uzasadnieniu wyroku podkreślono, że z chwilą wejścia w życie orzeczenia, stwierdzającego częściową niekonstytucyjność zakwestionowanego przepisu, art. 46 ust. 2 pr.pr. przyjmie brzmienie: Ściganie odbywa się z oskarżenia prywatnego. Podkreślono przy tym, że sentencja niniejszego wyroku sformułowana została przy zastosowaniu techniki derogacji fragmentów 
także, aczkolwiek w bardzo ograniczonym zakresie, podjęcie próby obrony przed manipulacją poprzez przepisy art. 23 i 24 k.c. stojące na straży dóbr osobistych. Znacznie szersze możliwości w tym zakresie przewidziano w odniesieniu do reklam w myśl ustawy z 16 kwietnia 1993 r. o zwalczaniu nieuczciwej konkurencji ${ }^{108}$.

Środki społecznego przekazu: prasa drukowana, radio i telewizja posiadają niezwykłą siłę i olbrzymie możliwości oddziaływania na całe społeczeństwo, ze szczególnym jednak uwzględnieniem niektórych jego grup. Działają na własny rachunek, praktycznie poza jakąkolwiek kontrolą, gdyż trudno poważnie traktować argument, że takową kontrolę sprawuje czytelnik kupując lub odmawiając kupna egzemplarza tzw. prasy drukowanej, oglądając lub nie oglądając program telewizyjny, słuchając lub nie słuchając radia. Siła inercji odbiorców jest ogromna. Przyzwyczaiwszy się do konsumowania wiadomości podawanych przez tzw. prasę drukowaną, do „konsumowania” informacji z radia i telewizji odbiorcy, zżymając się częstokroć na treść przekazów, nie znajdują jednak najczęściej w sobie dostatecznej determinacji aby ograniczyć czytanie gazet, nie oglądać telewizji, nie słuchać radia. Środki społecznego przekazu powoli tworzą państwo w państwie, nie są już ani czwartym stanem, ani czwartą władzą ${ }^{109}$, ale władzą pierwsza, drugą i trzecią - gdyż wiedzą jaki powinien być kształt stanowionego prawa, jak rządzić i jakie powinny zapadać wyroki. Jednocześnie starają się kontrolować wszystkie sfery życia publicznego, same uchylając się od jakiejkolwiek kontroli, stawiając się ponad prawem, domagając się nieformalnego immunitetu, który chroniłby ich przedstawicieli praktycznie przed wszelką odpowiedzialnością. Manipulując społeczeństwem, dziennikarze są narzędziami władzy niewybieralnej, niesuwerennej, a sprawowanej w imieniu podmiotów, które pozostają anonimowe i których cele są członkom społeczeństwa nieznane, gdyż odkryte być mogą w praktyce jedynie przez dziennikarzy.

jednostek redakcyjnych tekstu aktu normatywnego. Ten sam rezultat mógłby zostać osiagnięty, gdyby Trybunał Konstytucyjny - kierując się zasadą powściągliwości sędziowskiej - orzekł o częściowej niekonstytucyjności za pomocą wskazania pewnego zakresu niekonstytucyjności normy zawartej w art. 46 ust. 2 pr.pr. (formuła jest niezgodny z konstytucja $w$ zakresie, w jakim...). Trybunał, wybrawszy pomiędzy dwiema dopuszczalnymi technikami, kierował się troską o prawidłowe i jednolite rozumienie skutków prawnych wyroku w praktyce. Ponieważ nie można wykluczyć negatywnych skutków ewentualnego uznania przez organy stosujące prawo, że orzeczenie o niekonstytucyjności pewnego zakresu normy zawartej w przepisie jest wypowiedzią niewiążącą powszechnie (co się niestety zdarza), Trybunał zdecydował się zastosować formułę stwierdzającą niekonstytucyjność wyraźnie wskazanego fragmentu jednostki redakcyjnej art. 46 ust. 2 pr.pr. (podobnie: wyr. z dnia 14 czerwca 2004 r., P 17/03, OTK-A 2004, nr 6, poz. 57). Trybunał przy tej okazji stwierdził, że uchylanie się od publikacji sprostowań jest czynem godzącym w godność człowieka. Zob. w tym przedmiocie J. Sobczak, Prawo prasowe komentarz, Warszawa 2008, s. 881.

${ }^{108}$ Tekst jednolity Dz. U. 2003, Nr 153 poz. 1503 z późn. zm. Zob. w tym przedmiocie E. Nowińska, Zwalczanie nieuczciwej konkurencji. Zagadnienia cywilnoprawne, Kraków 2002, s. 80-179. Ustawodawca przewidział odpowiedzialność za reklamę wprowadzającą w błąd, wykorzystującą uczucia, nierzeczową, ukrytą, ingerująca w sferę prywatności (uciążliwą) oraz porównawczą. Zob. także J. Szwajaret, Ustawa o zwalczaniu nieuczciwej konkurencji komentarz, Warszawa 2000, s. 593 i n.; także Komentarz do ustawy o zwalczaniu nieuczciwej konkurencji, red. M. Zdyb, Lex 2011.

${ }^{109}$ Warto zauważyć, że Edmund Burke, a nieco później Thomas Babington Macaulay, nie mówili o dziennikarzach jako o czwartej władzy, lecz o czwartym stanie, dopiero z czasem termin „czwarty stan” został przekształcony w określenie „czwarta władza” i w tym brzmieniu wszedł do języka polityki. Zob. w tym przedmiocie J. Adamowski, Czwarty stan. Media masowe w pejzażu społecznym Wielkiej Brytanii, Warszawa 2006, s. 9-10. 


\title{
Freedom of Speech and the Phenomenon of Press Release Manipulation
}

\begin{abstract}
Summary
The legal concept of human liberties and rights, including freedom of speech, is secondary to philosophical assumptions. Certainty of where the border between authority and freedom lies leaves the issue of the actual range of freedom unresolved. There is no, and there can be no absolute freedom, and the borders of every freedom are defined by legal regulations. This raises the question of whether a democratic state, a state of law, can make regulations in the realm of human rights and freedoms. In international relations, human rights are the foundation of all humanitarian law. There can be no violation of human rights in democratic states. The Constitution of Poland prioritizes human freedoms and rights in the constitutional hierarchy. Freedom of speech is placed particularly high in the hierarchy of liberties encompassed by human rights. Freedom of speech is guarded not only by Constitutional regulations but also detailed laws, which simultaneously establish the limits of the freedom of speech. These limits are also set by ethical norms. Journalists attempt to get around the legal limits that establish the framework of freedom and the barriers posed by codes of ethics, by means of manipulation of press releases. Manipulating society, journalists become a tool of authorities that are frequently not elected, not sovereign and are in fact acting on behalf of entities that remain anonymous and whose goals are undisclosed.
\end{abstract}

